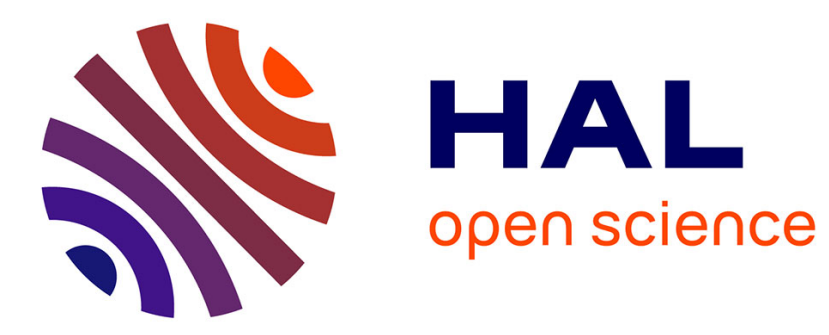

\title{
Geomorphological map of the Tiwanaku River watershed in Bolivia: implications for past and present human occupation
}

\author{
Marc-Antoine Vella, Nicolas Loget
}

\section{- To cite this version:}

Marc-Antoine Vella, Nicolas Loget. Geomorphological map of the Tiwanaku River watershed in Bolivia: implications for past and present human occupation. CATENA, 2021, 206, pp.105508. 10.1016/j.catena.2021.105508 . hal-03360090

\section{HAL Id: hal-03360090 https: / hal.sorbonne-universite.fr/hal-03360090}

Submitted on 30 Sep 2021

HAL is a multi-disciplinary open access archive for the deposit and dissemination of scientific research documents, whether they are published or not. The documents may come from teaching and research institutions in France or abroad, or from public or private research centers.
L'archive ouverte pluridisciplinaire HAL, est destinée au dépôt et à la diffusion de documents scientifiques de niveau recherche, publiés ou non, émanant des établissements d'enseignement et de recherche français ou étrangers, des laboratoires publics ou privés. 
1 Geomorphological map of the Tiwanaku River watershed in Bolivia: implications for past and present human occupation

Vella Marc-Antoine ${ }^{1,2, *}$ and Loget Nicolas ${ }^{3}$

1. Institut Français d'Etude Andines, IFEA, UMIFRE 17 CNRS/MAEDI, La Paz, Bolivia

2. Sorbonne Université, CNRS-INSU, Institut des Sciences de la Terre de Paris, METIS UMR 7619, F75005 Paris, France

3. Sorbonne Université, CNRS-INSU, Institut des Sciences de la Terre de Paris, ISTeP UMR 7193, F-75005

Paris, France

*. Corresponding author: Vella Marc-Antoine, mav.vella@gmail.com

UMR 7619 METIS - case courrier 105 - Sorbonne Université - 4 place Jussieu - 75252 Paris Cedex 05 France

\section{Abstract}

The Altiplano and more specifically the Titicaca circum-lake sector have recorded several major landscape transformations. In particular, changes in the lake water level lead to a significant vulnerability and contributed to the development of flexible and diverse agropastoral activities of the pre-Columbian and current populations to climate change. The Tiwanaku River, particularly because of the presence of the pre-Columbian Tiwanaku site, has been the subject of several research studies aimed at characterizing the environment of the archaeological site. Here we propose a new synthesis of the geomorphology of the Tiwanaku River watershed based on an interdisciplinary approach (Historical geography and remote sensing, cross combined with field survey). Our results show that the general organization of the drainage system is influenced by lake level and climatic changes. However several watercourses of the Tiwanaku River might be related to pre-Columbian agricultural or protourban structures. Our work allowed to estimate the regressive pattern of the coastline of Lake Titicaca and to identify major changes of the terminal and medium watercourse of the Tiwanaku River over the last 70 years. 
Keyword: Geomorphological map, remote sensing, historical aerial photography, Titicaca Lake, Tiwanaku River, Bolivia.

\section{Introduction}

The Altiplano is a high plateau (between 3600 and $4200 \mathrm{~m}$ asl (Above Sea Level)) of about $190000 \mathrm{~km}^{2}$, surrounded by peaks rising to over $6000 \mathrm{~m}$ altitude (Fig. 1A). The Altiplano lacustrine system (TiticacaDesaguadero-Poopó-Coipasa Salt Lake) is the result of early Pleistocene evolution that induces considerable variations in the lake level (Argollo and Mouguiart 2000, Baker et al. 2001a, Delclaux et al. 2007, Guerin et al. 2001, Revollo 2001, Talbi et al. 1999).

Holocene climatic evolution, identified from the study of lacustrine sediments, shows that Lake Titicaca (7131 km², mean depth $100 \mathrm{~m}$, max depth $285 \mathrm{~m}$ ) and its southern sub basin (Lake Wiñaymarka, 1428 $\mathrm{km}^{2}$, mean depth $9 \mathrm{~m}$, max depth $40 \mathrm{~m}$ ) has undergone several major fluctuations (up to $15 \mathrm{~m}$ ) (Abbott et al. 2003, Abbott et al. 1997, Baker et al. 2001b, Dejoux and Iltis 1992, Delaere 2019, Mourguiart et al. 1998, Rowe et al. 2004, Servant et al. 1995, Weide et al. 2017). Although some sedimentary formations have been described and mapped in the lake's vicinity, few conclusions about the influence of lake level variations on the local sediment routing system or the stratigraphic organization have been proposed (Baucom and Rigsby 1999, Farabaugh and Rigsby 2005, Rigsby al. 2003, Servant and Servant-Vildary 2003). On the other hand, long term archaeological occupation have been found in most valley systems surround Lake Titicaca (Capriles et al. 2014, Craig et al. 2010, Erickson 2000, Hastorf et al. 2005, Silverman and Isbell 2008, Stanish 2003). The valleys located in the southern part of the Lake Wiñaymarka (Tiwanaku, Katari and Desaguadero River), are one example among other that highlight this continuity (Albarracin-Jordan and Mathews 1990, Bandy 2006, Hastorf 1999, Isbell and Silverman 2002, Janusek 2008, Kolata 2003). It has been shown that during Holocene times, some preColumbian civilizations emblematic of the central Andean sector have developed, then disappeared possibly related to the lacustrine landscape evolution and prolonged drought (Arnold et al. 2021, 
Binford et al. 1997, Kolata and Ortloff 1996, Ortloff and Kolata 1992). There is still a strong controversy about the chronology and a lot of critique of the environmentally-driven view of pre-Columbian cultures collapse in Lake Titicaca area (Erickson 1999, Graffam 1992, Bandy 2005, Stanish 2003, Janusek 2004). Taking into account the complex relationship between ancient civilization and their environment, it is needed to understand the interactions between allogenic forcing of the natural system and human adaptations. As such, this paper proposes to establish a reliable cartography of the superficial sedimentary formations at the scale of the watershed of the Tiwanaku River.

Many superficial geological data are available in the Tiwanaku area, but to our knowledge, no attempts have been made to propose a regional geomorphological synthesis at the scale of the watershed. The realization of a new geomorphological map in the Tiwanaku valley aims to better constrain the pattern of geomorphic entities in regards of climatic and anthropogenic evolutions. This work also allows to better define and represent the relationships between the Holocene variations of the lake level and the response of the geomorphological system including the morphologic evolution of the valley. We show that the dynamics of the landscape are still active until recent times attested by the high mobility of the lake coastline and river positions over the last 70 years.

Finally, the occurrence of remnant canals, sukka kollus and kochas attest that the Tiwanaku valley can be considered as an ancient agricultural landscape as suggested by previous studies (Erikson 2003, Kolata 2003). 


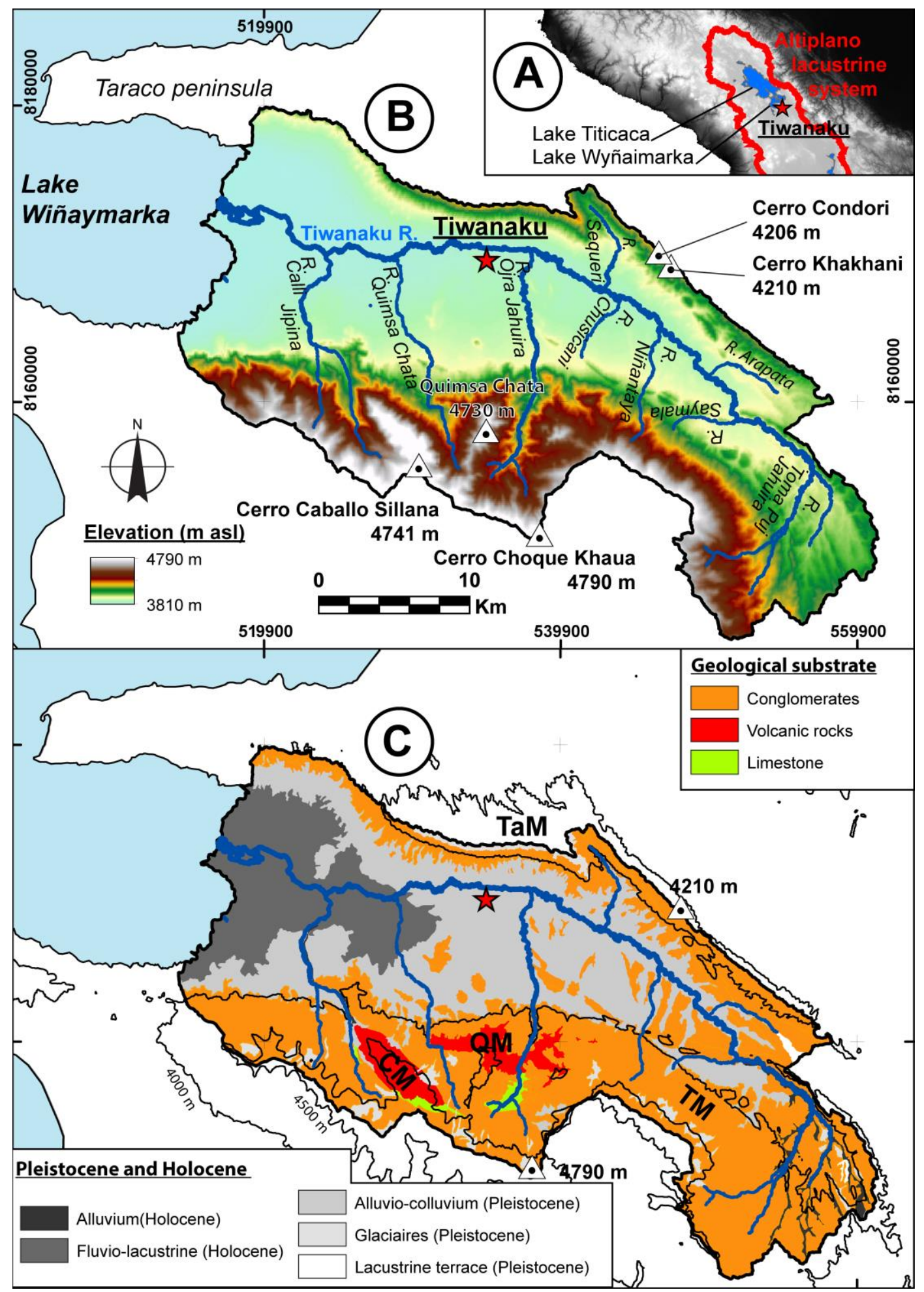

Fig. 1: Geomorphological characteristics of the Tiwanaku watershed. A: Location of the study area in

South America. B: Geographical features and main rivers (topography: ASTER GDEM; Coord. System

79 UTM WGS 1984 zone 19S Lat., Long. in meters). C: Simplified lithology (after GEOBOL 1994, modified).

Tiwanaku mountain range (TM); Chilla mountain range (CM); Quimsa Chata mountain range (QM);

Taraco mountain range (TaM). 


\section{2. Background}

84

85

\subsection{Geographical context}

The Tiwanaku River, east-west oriented, is located $75 \mathrm{~km}$ northeast of La Paz. This river, about $64 \mathrm{~km}$ long, flows into Lake Wiñaymarka (southern sub lake of the Lake Titicaca) located in the south of the Taraco peninsula (Fig. 1B). The topography of the watershed $\left(\sim 820 \mathrm{~km}^{2}\right)$ is flanked by the Taraco mountain range on the northern side and the Tiwanaku mountain range on the southern side. The northern flank reaches a maximum altitude of about $4200 \mathrm{~m}$ asl (Cerro Condori $4206 \mathrm{~m}$ asl, Cerro Khakhani $4210 \mathrm{~m}$ asl), the southern slope reaches almost $4800 \mathrm{~m}$ asl (Cerro Choque Khaua $4790 \mathrm{~m}$ asl, Cerro Caballo Sillana $4741 \mathrm{~m}$ asl, Cerro Quimsa Chata $4730 \mathrm{~m}$ asl) while the alluvial plain is located at $\sim 3815 \mathrm{~m}$ asl. The Tiwanaku watershed shows a strong asymmetry with large southern tributaries (from upstream to downstream: Toma Puj Jahuira River, Saymala River, Niñantaya River, Chusicani River, Ojra Jahuira River, Quimsa Chata River, Calli Jipina River) and short northern tributaries (from upstream to downstream: Arapata River, Sequeri River). The pattern of the Tiwanaku River presents a braided morphology in the upstream part evolving to a meandering system in the middle and lower valley. It finally flows in Lake Wiñaymarka by forming a lacustrine delta (3810 m asl). 


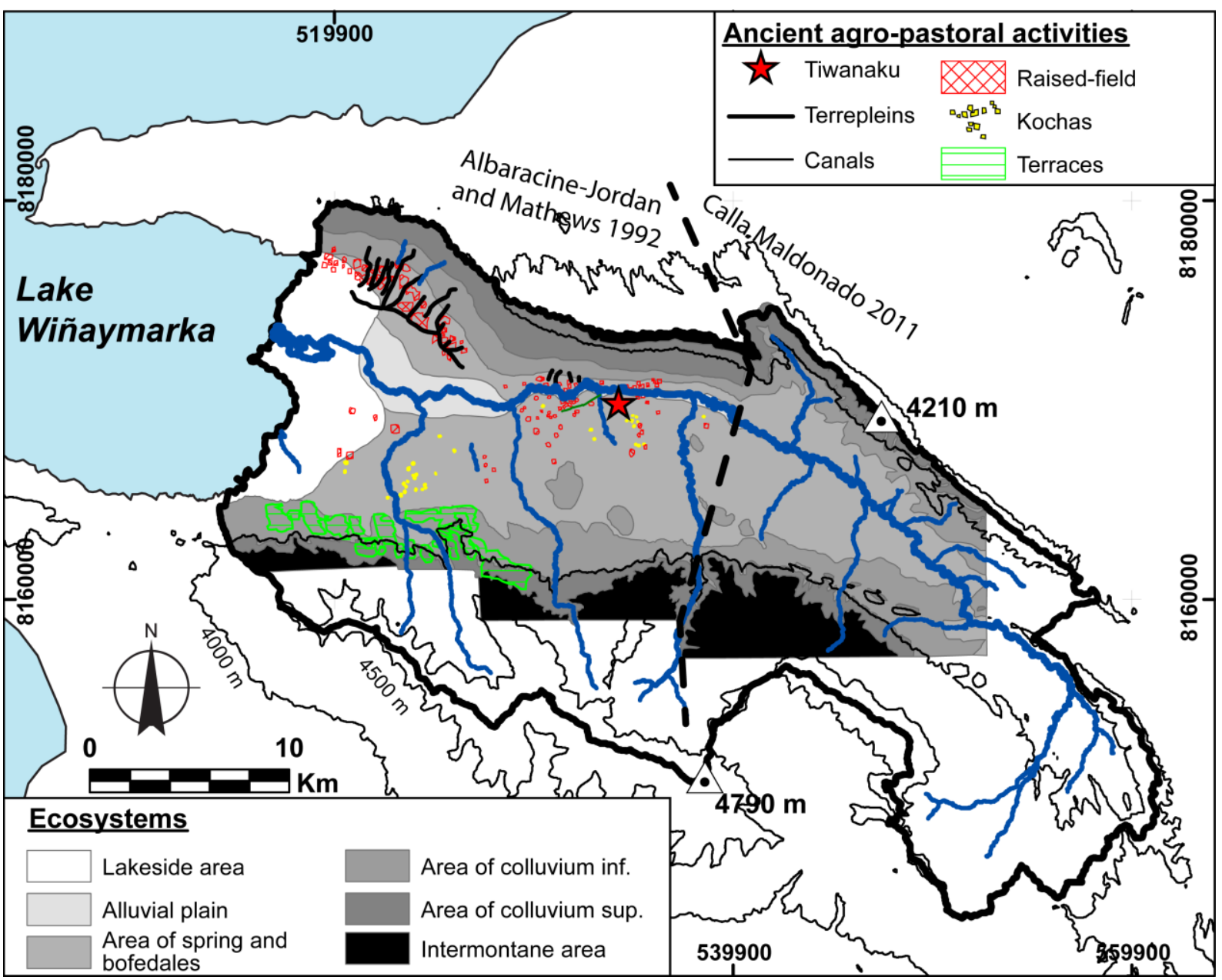

Fig. 2: Geoarchaeological map of the Tiwanaku valley (modified after Albaracine-Jordan and

Matthews 1992, Calla Maldonado 2011).

\subsection{Geological context}

The Tiwanaku watershed is located on the Altiplano that represents a low-relief, internally-drained basin flanked between the Eastern Cordillera (uplifted core of the central Andean fold and thrust belt) and the Western Cordillera (modern volcanic arc) (Baucom and Rigsby 1999). The Altiplano basin is mainly filled with Cenozoic sedimentary and volcanic rocks. The Tiwanaku area is composed of several geological formations roughly linked to the late geological evolution of Atliplano.

The southern part of the Tiwanaku valley is flanked by the Tiwanaku mountain range oriented SE-NW, and composed of highly folded sandstone and argillite dating from the Tertiary (Fig. 1C). This range is 
111 the Upper Miocene. Glacial formations dated from Pleistocene can be mainly observed on this 112 southern flank. The northern flank is characterized by the Taraco mountain range. It is composed of 113 conglomerates of the Coniri, Kollu Kollu (Oligo-Miocene) and Taraco (Pliocene) formations, organized 114 in a NW-SE folded structure (Argollo 2003, GEOBOL 1994). Paleolimnological studies on Lake Titicaca 115 identified large and rapid lake-level fluctuations during the Quaternary (Abbott et al. 1997, Abbott et 116 al. 2003, Delaere 2017, Fritz et al. 2004, Mourguiart et al. 1998, Rowe et al. 2003, Servant and Servant117 Vildary 2003, Theissen et al. 2008, Weide et al. 2017). Some lacustrine terraces can be observed in the 118 lower parts of the Tiwanaku valley (between 3815 and $3940 \mathrm{~m}$ asl) and are related to Pleistocene high 119 lake stands (Argollo 2003). The Bolivian Altiplano is a tectonically quiescent plateau situated between 120 the fold-and-thrust belt of the eastern Cordillera and the active arc of the western Cordillera (Baucom 121 and Rigsby 1999). The occurrence of tilted paleo shorelines associated to the Pleistocene Lake Minchin 122 and located above the current Titicaca's shoreline, indicated some large scale tilting processes over 123 the last $17 \mathrm{ky}$ in the central Altiplano (Bills et al. 1994). 


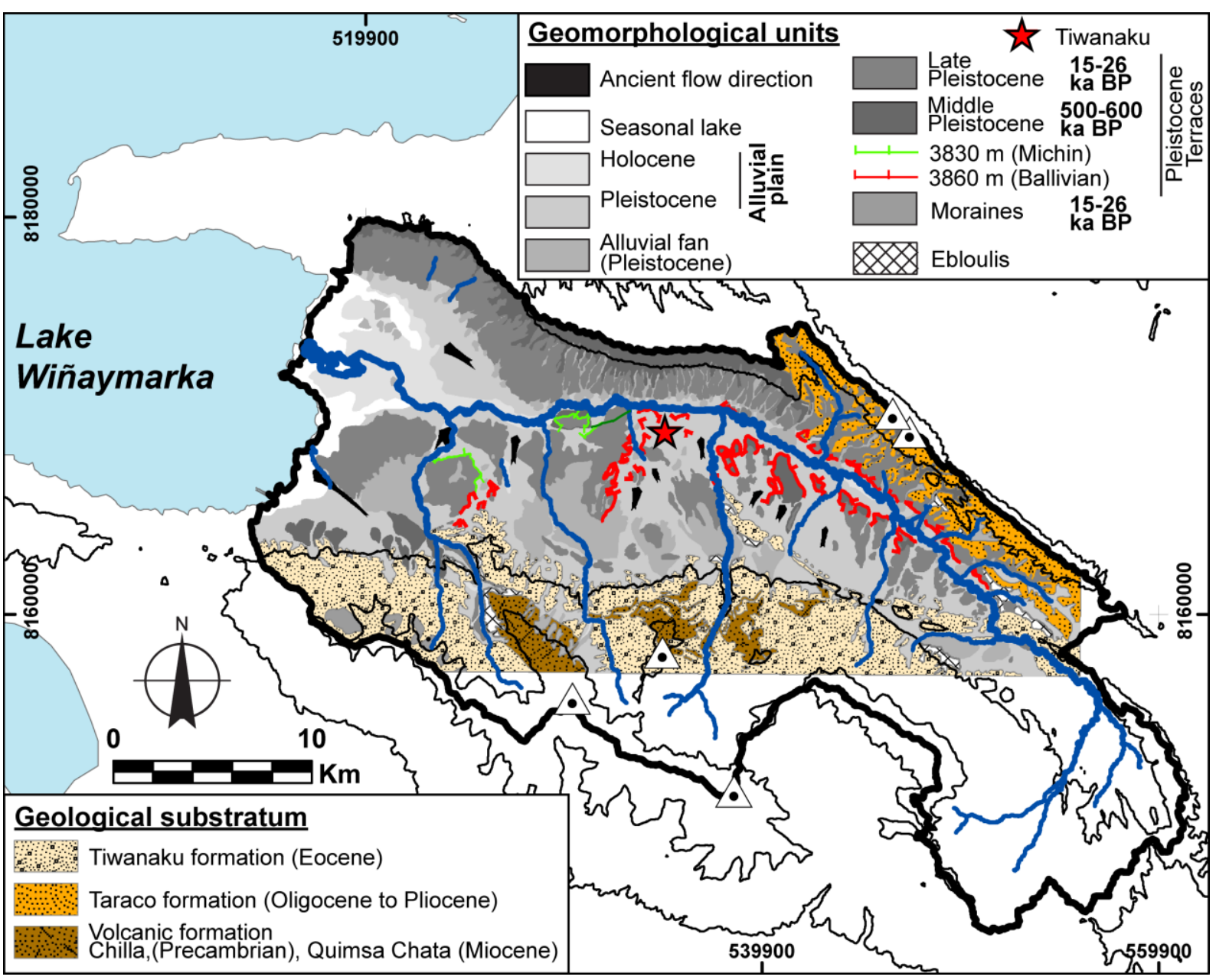

125 Fig. 3: Geomorphological map of the Tiwanaku valley (after Argollo 2003).

\subsection{Holocene alluvial and lake level variations}

The fluvial and lacustrine terraces as well as incision features of the Tiwanaku River can be linked to

Lake Titicaca variations (Abbott et al. 1997, Baker and Fritz 2015, Delaere 2017, Martin et al. 1993,

Mourguiart et al. 1998, Roche et al. 1992, Rowe et al. 2003, Weide et al. 2017). ). Annual variations can

be correlated to the tropical Andean South American Summer Monsoon rainfall (SASM) (Bird et al. 
at centennial to millennial timescales precipitation levels in the Altiplano are linked to shifts in the

138 Intertropical Convergence Zone (ICTZ) over the tropical Atlantic and Pacific (Abbott et al. 2003, Arnold

139 et al. 2021).

140 Lake Titicaca experienced long phases of drought with lake levels sometimes much lower than the

141 current one, in particular around 8000 BP (Abbott et al. 1997, Abbott et al. 2003, Fritz et al. 2004,

142 Weide et al. 2017, Wirrman et al., 1992).The Late Holocene water-level fluctuations in Lake

143 Wiñaymarka evolved with (i) a minor lake-level rise $(6-8 \mathrm{~m})$ around $4000 \mathrm{BP}$ (Wirrmann and

144 Mourguiart 1995), (ii) a rapid 15-20 m lake-level rise around 3500 BP and (iii) 4 major cycles of lake-

145 level transgression and regression during this global high-level stage (3200-2800 cal yr BP, 2200-2000

146 cal yr BP, 1650-1450 cal yr BP, 900-700 cal yr BP; Abbott et al. 2003, Abbott et al. 1997, Binford et al.

147 1997). Studies from the main basin of Lake Titicaca (Baker et al. 2001a, Seltzer et al. 1998) indicate that

148 Lake Titicaca was below the modern spill level until at least $3000 \mathrm{BP}$. The current period reached a

149 maximum lake level in the $17^{\text {th }}$ and $18^{\text {th }}$ centuries (Wirrmann 1988) and can be correlated to the wet

150 period of the Little Ice Age (LIA, Mourguiard et al. 1997, Rabatel et al. 2008, Thompson et al. 1986). The

151 lake water level fluctuated more than six meters during the $20^{\text {th }}$ century (Roche et al. 1992).

152 Holocene sedimentary formations of fluvial origin are characterized by two or three continuous

153 sequences of fine deposits (clay, silts, sand and gravel) with intercalations of peat levels. These

154 sedimentary formations are related to the evolution of alluvial fans at the base of the slopes of the

155 valley in relation to an anastomosed hydrological system with small channels (Argollo et al. 2003). A

156 significant number of sources are still located at the base of the main mountain ranges. The modern

157 rivers occupy the channel carved out by the last incision episode (900-700 cal yr BP). Studies from Lake

158 Wiñaymarka suggest that between 3500-700 BP, the Desaguadero River was not an effective outlet

159 from Lake Titicaca (Abbott et al. 1997). However, all previous lake level changes have not been clearly

160 identified within alluvial formations. Studies on Desaguadero, llave and Ramis Rivers indicated that

161 after $3300 \mathrm{yr} \mathrm{BP}$, the terrace formation is the result of at least three rapid water-level falls and

162 migration of the River (Baucom and Rigsby 1999, Farabaugh and Rigsby 2005). Previous studies 
reported also stabilization phase valleys of the Altiplano presented evidences of soil formation during the early Holocene (between 8350-6780 BP, (Rigsby et al. 2003), followed by large incisions (6045-4545 BP; Farabaugh and Rigsby 2005, Servant and Servant-Vildary 2003) and two periods of sedimentary filling of the valleys coinciding with a phase of lake-level rise and overflow (4045 BP-2545 BP and 20451645 BP; Baucom and Rigsby 1999, Farabaugh and Rigsby 2005, Rigsby et al. 2003). During the late Holocene, studies suggest that precipitation may have decreased slightly over the Amazon Basin during the last 2200 years while Andean precipitation continued to increase (Bird et al. 2011). Subsequent downcutting occurred after approximately 1600 yr BP but could not be chronologically located.

\subsection{Geomorphological mapping}

The Holocene sedimentary formations of the watershed are still insufficiently studied. Since the 1990's, some studies have characterized the large ecological and geomorphological units of the lower and middle valley. However, they are not based on the same cartographic methods and not mapped at the regional catchment scale (Fig. 2 and 3). The Table 1 summarize geomorphological features used for previous mapping as mainly based on remote sensing, historical photography and field acquisition at the watershed scale. 


\begin{tabular}{|l|l|l|l|}
\hline \multicolumn{2}{|l|}{$\begin{array}{l}\text { Albarracin-Jordan and Mathews 1990, Calla } \\
\text { Maldonado } 2011\end{array}$} & \multicolumn{2}{l|}{ Argollo 2003} \\
\hline Elevation & Feature & Elevation & Feature \\
\hline $4100-4800 \mathrm{~m}$ & $\begin{array}{l}\text { inter-mountainous areas (IM): } \\
\text { rocky landscapes }\end{array}$ & $\sim 3940 \mathrm{~m}$ & $\begin{array}{l}\text { T7: paleolake Mataro, early } \\
\text { Pleistocene ( 1.6 million years } \\
\text { ago) }\end{array}$ \\
\hline $4000-4100 \mathrm{~m}$ & $\begin{array}{l}\text { Upper Colluvial Zone (UCZ): } \\
\text { deep quebrada with gravel } \\
\text { sedimentary filling }\end{array}$ & $\sim 3900 \mathrm{~m}$ & T6: early Pleistocene \\
\hline $3900-4000 \mathrm{~m}$ & $\begin{array}{l}\text { Lower Colluvial Zone (LCZ): } \\
\text { peat and gravel }\end{array}$ & $\sim 3880 \mathrm{~m}$ & T5: middle Pleistocene \\
\hline $3820-3900 \mathrm{~m}$ & $\begin{array}{l}\text { Springs and bofedales (SB): } \\
\text { peat and clay soils }\end{array}$ & $\sim 3860 \mathrm{~m}$ & $\begin{array}{l}\text { T4: paleolake Ballivian middle } \\
\text { Pleistocene, 600 - 500 ky ago) }\end{array}$ \\
\hline $3820-3840 \mathrm{~m}$ & $\begin{array}{l}\text { Alluvial plain (AP): sandy loam } \\
\text { sediments }\end{array}$ & $3860-3825 \mathrm{~m}$ & $\begin{array}{l}\text { T3: paleolake Michin 46-36 ky } \\
\text { BP }\end{array}$ \\
\hline \multirow{2}{*}{$3809-3820 \mathrm{~m}$} & $\begin{array}{l}\text { Lacustrine zone (LZ): } \\
\text { intermittently emerged area } \\
\text { associated with seasonal } \\
\text { variations of the lake }\end{array}$ & $3818-3815 \mathrm{~m}$ & $\begin{array}{l}\text { T2: paleolake Tauca } ~ 26-15 \mathrm{ky} \\
\text { BP }\end{array}$ \\
\cline { 2 - 5 } & $<3810 \mathrm{~m}$ & T1: Holocene \\
\hline
\end{tabular}

The 1990's geomorphological pioneers' works are based on an altimetric approach and aims to reconstruct the large ecosystems forming the valley (Albarracin-Jordan and Mathews 1990) (Fig. 2).

More recently, Calla Maldonado's (2011) work used a similar method to deduce the occupation strategies of pre-Hispanic societies that occurred in the middle valley. They distinguish 6 ecosystems (lacustrine zone, alluvial plain, springs and bofedales, Lower Colluvial Zone, Upper Colluvial Zone, intermountainous areas (Fig 2).

The work carried out by Argollo et al. (2003) is based on the geological composition of the subsoil. It provides detailed information on the location of Pleistocene and Holocene lacustrine formations in the lower valley (Fig. 3). Some terraces are associated with dated paleo shorelines (Bills et al. 1994, Servant 201 et al. 1995, Sylvestre et al. 1999) and were related to high levels of Lake Titicaca (Argollo et al. 2003, 202 Fritz and al. 2004, Mourguiard et al. 1997, Servant et Fontes 1978, 1984). Argollo et al. (2003) showed 203 that the mountain range and the Taraco peninsula present a topography cut by several terraces of low 204 slope (between 1 and $5 \%$ ). 
Because of the scattering of geological and geomorphological data, no homogenized map exists in this

area. In this paper, we propose to complete and merge existing mappings in order to obtain a regional mapping of the watershed. We then complement these observations with an innovative interdisciplinary approach that combines the methods of remote sensing, historical geography (old and recent aerial photographs) and field techniques on poorly studied areas.

\subsection{Pre-Columbian agricultures and landscape inheritances}

During the late Holocene and at the scale of Mesoamerica and South America, raised-field agriculture in wetlands was conducted in a wide range of environments from sea level to over $4000 \mathrm{~m}$ elevation, covering a great range of soils and climates (Renard et al. 2012). Among other examples, raised fields have been found in the Basin of Mexico (e.g., Sanders et al. 1979), in the Altiplano of Bolivia and Peru (Erickson 1992, 2003, Kolata 1996), within inter-Andean valleys marshes (Wilson et al. 2002), were also related to seasonally flooded savannahs in the lowlands (Plazas and Falchetti 1990, Reichel-Dolmatoff and Reichel-Dolmatoff 1974, Rostain 2008, Spencer et al. 1994, Walker 2004) and even in southern regions of Chile (Dillehay et al. 2007). Massive irrigation networks created as early as 4000 BP in desert coastal valleys of Peru, turned them into productive landscape for prehistoric inhabitants and provided the foundations for complex society (Moseley 1983). The $113 \mathrm{~km}$ long Chicama-Moche intervalley canal combining aqueducts and other sophisticated hydraulic structures constructed by the Chimu around AD 1400 is another example among other of water management knowledge (Erickson 1992). Previous studies in the Tiwanaku valley identified 3 types of agro-pastoral systems (Albarracin-Jordan and Mathews 1990, Kolata 2003). They distinguished the terraces of cultures, the kochas (artificial ponds of circular shape used for water retention, sometimes organized in groups connected by channels) and the sukka khollus (platforms of raised cultures organized in networks connected with natural and artificial channels). These inherited agricultural technics from the pre-Columbian civilizations attest to human adaptation to the environment (Kolata 2003). Raised field agriculture (sukka khollus) provided pre-Columbian farmers with better drainage and protection against flooding, 
soil aeration, moisture retention during the dry season and a fertility advantage. It also aimed at conserving water for long- and short-term droughts, using the stored water to extend growing seasons (Erickson 1992). This agricultural technic offers also more favorable microclimates as a greater frost tolerance in cold highland environments (Erickson 1992, Kolata and Ortloff 1989, Lhomme and Vacher 2002). Raised field from the Altiplano were cultivated beginning about 3000 years ago and formed much of the subsistence basis for the Tiwanaku Empire (Kolata 1996). Finally, Kolata (2003) highlights the existence of partial regularization of the Tiwanaku River, canals and platforms in association with raised fields in the lower and middle valleys. However, no chronological control exist to relate these landscape modifications. There is consensus that these canals and raised fields are attributed to the Tiwanaku culture (400-1150 AD) but a controversy still exists on the chronology of disappearance of these integrated regional agricultural system (Abbott et al. 1997, Erickson 1999, Graffam 1992, Janusek and Kolata 2004, Kolata et al. 2000, Ortloff and Kolata 1992, Vranich 2013).

\section{Methods and technics}

\subsection{Remote sensing}

We used Landsat 8-level 2 satellite image (date: 2016-september-18; multispectral 30 m, panchromatic $15 \mathrm{~m}$ and thermic $60 \mathrm{~m}$ resolution), Advanced Spaceborne Thermal Emission and Reflection Radiometer (ASTER) Global Digital Elevation Model Version 3 (GDEM 003) ( 30m pixel resolution) and Shuttle Radar Topography Mission Version 3.0 Global 1 arc second (SRTM 3) (SI Fig. 3) centered at the watershed scale. Landsat 8 and ASTER and SRTM 3 data were downloaded from the USGS (United State

Geological Survey) Earth explorer website (earthexplorer.usgs.gov) and processed using Arcgis 10.3 software.

Remote sensing has long been used to characterize the wetlands within the Altiplano (Moreau et al. 2003, Moreau and Le Toan 2003, Otto et al. 2011, Vining and Williams 2020). Altiplano wet grasslands are composed of two distinct category of vegetation. The totora is a perennial reed (Cyperaceae family) 
which grows in water up to $5.5 \mathrm{~m}$ depth or in inland areas subject to summer flooding. The bofedales are characterized by permanently water-saturated highland short grasslands with over 60 plant species forming a dense carpet ( $\sim 9 \%$ vegetation cover), crisscrossed during the wet season by seasonal shallow streamlets (Moreau and Le Toan 2003). Most of the valley vegetation is composed of bunchgrass (Festuca sp. and Stipa sp.) and/or low shrubs (Parastrephia sp.) (Vining and Williams 2020). Some scattered trees like eucalyptus are present near most important villages. Other type of vegetation in the Altiplano include trees like Polylepis sp. among other but are not represented in the Tiwanaku valley.

In order to characterize the hydric and vegetation state we calculated the NDVI index (Normalized Difference Vegetation Index) that corresponds to the normalized difference between red and nearinfrared (NIR) energy reflectance of the vegetation cover (Bharathkumar and Mohammed-Aslam 2015, D'Allestro and Parente 2015, Gandhi et al. 2015, Tucker 1979). The NDVI calculation was processed in a GIS environment using the following formula:

$\frac{(\mathrm{NIR}-\mathrm{Red})}{(\mathrm{NIR}+\mathrm{Red})}=N D V I$ where Red $=$ band $4, \mathrm{NIR}=$ band 5 and $-1<\mathrm{NDVI}<1$.

This vegetation index enables to distinguish the density of the vegetation cover (wet grassland, ie. totora and bofedal), waters (lakes, rivers, kochas and wetland) and soils (rocks, buildings, roads). Vegetated areas generally present relatively high near-infrared reflectance and low red reflectance and are associated to positive NDVI values; water and wet area present negative values as these features have larger reflectance in Red than in NIR. Rock and bare soil areas have similar reflectance in the two bands and produce values near zero. (D'Allestro and Parente 2015). In partial and sparse vegetation cover like the Altiplano, senescent plant reflectance converges with bare soils (Vining and Williams 2020). However, wet grasslands are the only native forage resources available around the year, including during the dry winter season (Moreau et al. 2003). The comparison of the evolution of the monthly mean NDVI and map (SI Tab. 1, SI Fig 1 and 2) along a year demonstrated that September was the most accurate period to distinguish wet grassland from bare soil area (SI Text). 
281 We also extracted the slope from GDEM ASTER in order to access to basic geomorphic parameters of 282 the watershed. We then classified the slope map following the approach of Touahir et al. (2018), which 283 considers that the slope ranges of $0-5 \%, 5-15 \%, 15-35 \%$, and $>35 \%$ correspond to low, medium, high 284 and very high erosion domains, respectively. The GDEM ASTER was also used to extract drainage maps 285 whose protocol is detailed in Supplementary Information with a specific focus on differences between 286 ASTER and SRTM 3 results. 


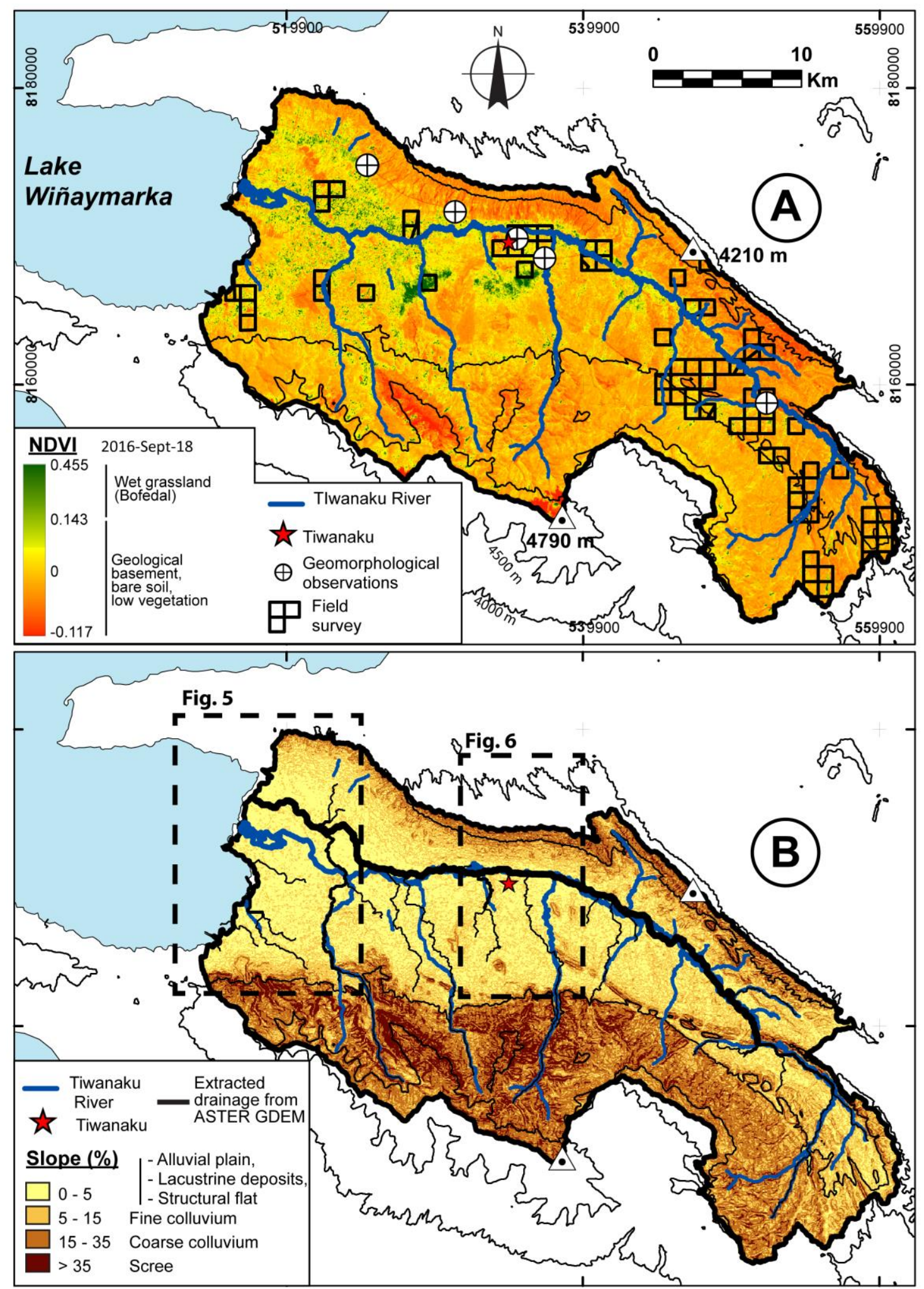

Fig. 4: Remote sensing and geomorphic parameters obtained on the Tiwanaku River watershed. A: 
Survey). The sectors that were the subject of field surveys are represented. B: Slope map and flow map (From ASTER data, source: U.S. Geological Survey). Location of Fig. 5 to 8 are represented.

\subsection{Historical geography}

For this study, we have compiled and georeferenced the geological, topographic, geomorphological maps and historical aerial photos taken between the 1930's and 2019 in an ArcGIS environment (Tab.

2, Fig 5 and 6, SI Fig. 4). The oldest cartographic documents available (dated from 1930), were acquired specifically around the Tiwanaku archaeological site (1 mosaic, $4.84 \mathrm{~km}^{2}$ ) (Ortloff 2014). The 1954-1955 and 1972 aerial photographs were obtained by the Bolivian national services. The 19541955 campaign concerned the full catchment area (110.25 km², 72 tiles), whereas the 1972 campaign was restricted to the medium course of the Tiwanaku River (1.4 km², 14 tiles). 2014 and 2019 satellite images were obtained from the U.S. Geological Survey database. 2017 aerial photographs of the Tiwanaku area were obtained from the Guaquira-Tiwanaku archaeological mission. All aerial photographs allow us to distinguish the channels of the Tiwanaku River, wetlands and the shoreline for each period. We completed this geodataset with published topographic maps reporting alluvial, lacustrine and shoreline positions mapping between 1983 and 1985 by the IGM (1985). 


\section{River drainage system.}

\begin{tabular}{|c|c|c|c|}
\hline $\begin{array}{l}\text { Docu } \\
\text { ment } \\
\text { type }\end{array}$ & Date & Source & Description \\
\hline $\begin{array}{l}\text { Aerial } \\
\text { photog } \\
\text { raphy }\end{array}$ & 1930 & Instituto Geográfico Militar de Bolivia & $\begin{array}{l}\text { Aerial photographs of the } \\
\text { archaeological site of Tiwanaku and } \\
\text { the alluvial plain }\end{array}$ \\
\hline $\begin{array}{l}\text { Aerial } \\
\text { photog } \\
\text { raphy }\end{array}$ & $1954-55$ & Instituto Geográfico Militar de Bolivia & $\begin{array}{l}\text { Aerial photo of the coastline and of } \\
\text { the alluvial plain from the middle } \\
\text { valley and the mouth }\end{array}$ \\
\hline $\begin{array}{l}\text { Aerial } \\
\text { photog } \\
\text { raphy }\end{array}$ & 1972 & Instituto Geográfico Militar de Bolivia & Aerial photo of the alluvial plain \\
\hline $\begin{array}{l}\text { Topogr } \\
\text { aphical } \\
\text { map }\end{array}$ & 1985 & Instituto Geográfico Militar de Bolivia & $\begin{array}{l}\text { Topographic map of the Tiwanaku } \\
\text { valley }\end{array}$ \\
\hline $\begin{array}{l}\text { Satellit } \\
\text { e image }\end{array}$ & 7/14/1986 & U.S. Geological Survey & $\begin{array}{l}\text { Landsat } 5 \text { TM-level } 2 \text {, satellite image } \\
\text { of the watershed }\end{array}$ \\
\hline $\begin{array}{l}\text { Satellit } \\
\text { e image }\end{array}$ & $8 / 2 / 1987$ & U.S. Geological Survey & $\begin{array}{l}\text { Landsat } 5 \text { TM-level } 2 \text {, satellite image } \\
\text { of the watershed }\end{array}$ \\
\hline $\begin{array}{l}\text { Satellit } \\
\text { e image }\end{array}$ & $7 / 11 / 2014$ & U.S. Geological Survey & $\begin{array}{l}\text { Landsat } 8 \mathrm{OLI} / \mathrm{TIRS} \text {-level } 2 \text {, satellite } \\
\text { image of the watershed }\end{array}$ \\
\hline $\begin{array}{l}\text { Aerial } \\
\text { photog } \\
\text { raphy }\end{array}$ & 2017 & Guaquira-Tiwanaku Project & $\begin{array}{l}\text { UAV aerial photos of the } \\
\text { archaeological site of Tiwanaku }\end{array}$ \\
\hline $\begin{array}{l}\text { Aerial } \\
\text { photog } \\
\text { raphy }\end{array}$ & 2019 & $\begin{array}{l}\text { Esri, DigitalGlobe, GeoEye, Earthstar } \\
\text { Geographics, CNES / Airbus, DS, USDA, } \\
\text { USGS, AeroGRID, IGN, and the GIS User } \\
\text { Community }\end{array}$ & Satellite image of the watershed \\
\hline
\end{tabular}



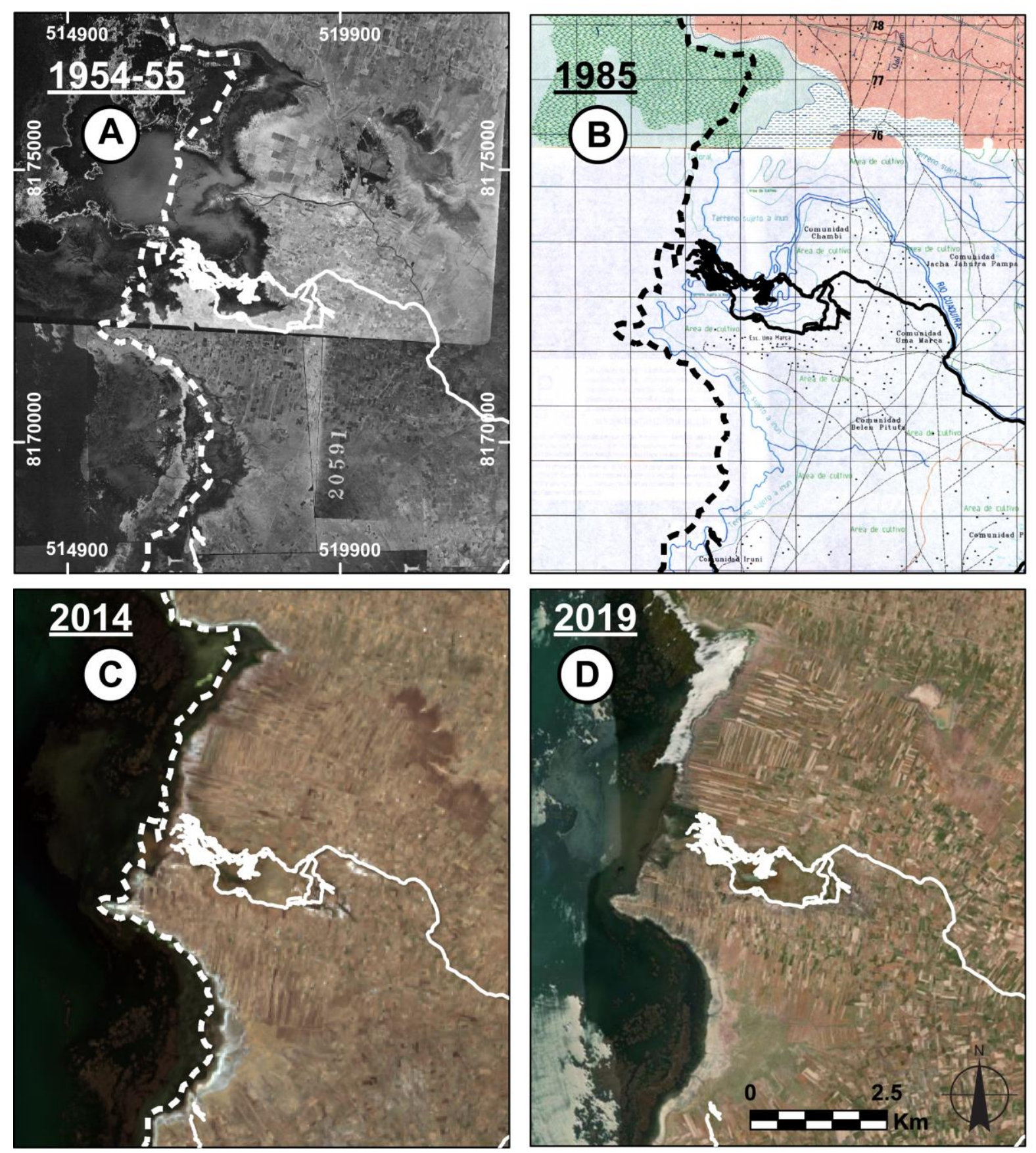

Fig. 5: Aerial photographs near the mouth of the Tiwanaku River in Lake Wyñaimarka. The dotted

321 line represent the current situation of the coastline and the continuous line the current location of the

322 Tiwanaku River. A. 1954-55. Source: Instituto Geográfico Militar de Bolivia. B. 1985. Source: Instituto

323 Geográfico Militar de Bolivia. C. 2014. Source: Landsat 8 OLI/TIRS-level 2 courtesy of the U.S. Geological

324 Survey. D. 2019. Source: Esri, DigitalGlobe, GeoEye, Earthstar Geographics, CNES / Airbus, DS, USDA,

325 USGS, AeroGRID, IGN, and the GIS User Community. 

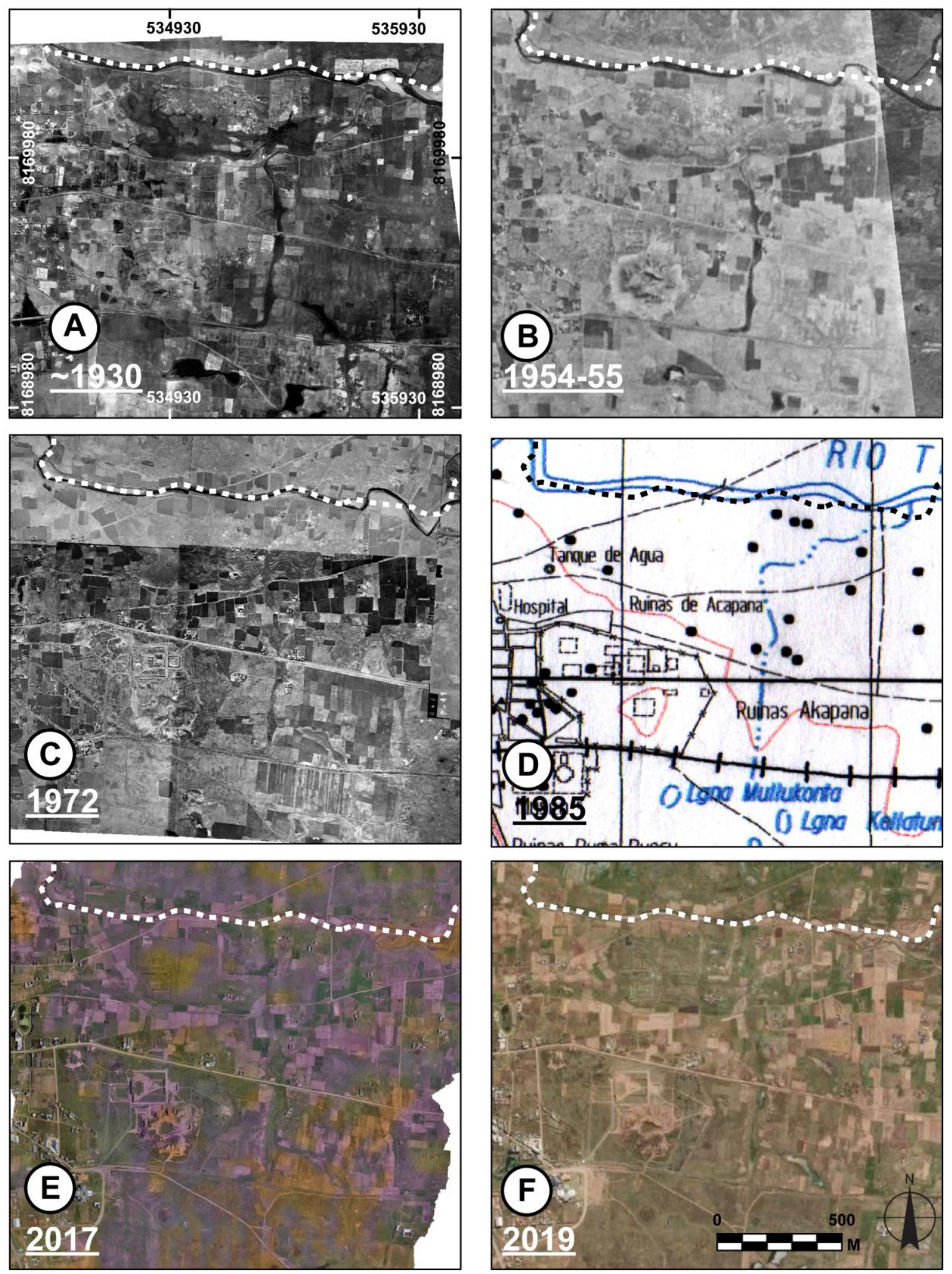

327 Fig. 6: Aerial photographs of the Tiwanaku archaeological site. The dotted line represent the current

328 situation of the Tiwanaku River. A. 1930'. Source: Instituto Geográfico Militar de Bolivia. B. 1954-55.

329 Source: Instituto Geográfico Militar de Bolivia. C. 1972. Source: Instituto Geográfico Militar de Bolivia.

330 D.1985. Source: Instituto Geográfico Militar de Bolivia. E. 2017. Source: Guaquira-Tiwanaku project. F. 

AeroGRID, IGN, and the GIS User Community.

\subsection{Field acquisition and observation}

Field survey areas (location in Fig. 4A) were selected based on remote sensing and historical geography analysis, which identified main geomorphological features (such as wetlands, slope deposits) or a high variation of alluvial or lacustrine forms (alluvial plain, lacustrine deposits). The methodology has been already described in a previous paper (Vella et al. 2018) and follows a strategy used by several works in this area (Albarracin-Jordan and Mathews 1990, Argollo et al. 2003, Calla Maldonado 2011). In order to best explore the diversity of the landscape, the field survey takes into account the physical boundaries of the watershed. In mountain areas, ridges and low topography levels were favored. In flat areas, profiles spaced $50 \mathrm{~m}$ apart were made. General explored area tries to represent several cross sections across strike and one along strike to what we added some random point.

For the purpose of our study we present six geomorphological sections (Fig. 4A). C1 is located in the lower valley, $\mathrm{C} 2$ to $\mathrm{C} 5$ are located in the middle valley, and C6 in the high valley. These sections allow for the characterization of the stratigraphy of the lower Pleistocene lake terrace and the Holocene alluvial deposits.

\section{Results}

\subsection{Remote sensing}

We used the NDVI map as a first order approximation to distinguish 3 main classes of vegetation cover and as an indirect indicator of geomorphological feature (ie. wet grassland (totora and bofedal); water and wet area; rock and bare soil areas) (Fig. 4A). In the Tiwanaku valley, during the month of September, NDVI values ranged from -0.117 to 0.455 . Water and wet areas are characterized by negative NDVI values (D'Allestro and Parente 2015) but no clear features associated to inland water 
bodies were identified in the Tiwanaku valley. Previous research on the Altiplano (Moreau et al. 2003, Moreau and Le Toan 2003) demonstrated that NDVI values ranging between 0.508 and 0.143 correspond to areas of wet grassland (totora and bofedal). They are mainly located along the Tiwanaku River (bofedal) and near the Lake Wiñaymarka (totora). These features are related to Pleistocene and Holocene alluvial plain as well as Holocene lacustrine deposits identified by previous studies (GEOBOL 1994). In particular, two sets of wet grassland (bofedal) stand out just on south of the Tiwanaku River in the middle valley. NDVI values ranging between 0.143 and 0 are located at high and medium elevation. These features are related to the geological basement, bare soils areas and to large domains where the vegetation is senescent. They coincide with a large part of lowlands and intermountain area identified by previous studies (Albarracin-Jordan and Mathews 1990, Calla Maldonado 2011).

We complemented the NDVI approach with slope classifications (Fig: 4B). The 0-5 \% slope range corresponding to low erosion domains represents the main part of the valley and is roughly centered on major floodplain. This low range value is due to the occurrence of flat landforms (alluvial plain, lacustrine and alluvial terraces, horizontal tertiary layers). Pleistocene and Holocene alluvial plain as well as Holocene lacustrine deposits are located at low elevation while Pleistocene lacustrine deposits are located above $3815 \mathrm{~m}$ asl. The $5-15 \%$ slope range corresponding to medium erosion domains is located at the foot of both mountain flanks (3940 to $4100 \mathrm{~m}$ asl). This domain also partially corresponds to the LCZ mapped in previous studies (Albarracin-Jordan and Mathews 1990, Calla Maldonado 2011). The $15-35 \%$ slope range corresponding to high erosion domains (4100 to $4500 \mathrm{~m}$ asl), coincide approximately with the UCZ described by previous studies (Albarracin-Jordan and Mathews 1990, Calla Maldonado 2011). The $>35 \%$ range slope corresponds to very high erosion domains ( $>4500 \mathrm{~m}$ asl) and are related roughly to intermountain areas described in previous studies (Albarracin-Jordan and Mathews 1990, Calla Maldonado 2011).

The extracted drainage flow roughly mimics the course of the actual Tiwanaku River except in the downstream part and for several south confluences. This implies that discreet slope changes, 
undetected by the DEM's resolution using for drainage extraction, have possibly modified the course of the recent Tiwanaku River.

Ancient agricultural systems composed of sukka kollus and kochas are located in low erosion sectors (0-5\% slope range). These features are associated with wet grassland area (bofedal, $0.143<N D V \mid<0.455)$ and bare soils area $(0<N D V \mid<0.143)$ respectively.

\subsection{Historical geography}

The resolution of the historical aerial photographs allows to track the mobility of alluvial and lacustrine origin landforms since the first half of the $20^{\text {th }}$ century. We mainly focus our analysis on Lake Wiñaymarka (Fig 5 and Fig. 7) and Tiwanaku archaeological areas (Fig. 6 and Fig. 8). On both areas, several ancient river courses and/or canals are present on most ancient cartographic documents available. As these features could not be related to a specific period they were mapped as undated.

We have mapped coastline variations of the Lake Wiñaymarka observed between 1954-1955 and 2019

(Fig 5 and Fig. 7). The displacement of the coastline shows a regressive pattern and can be estimated, on average, at $400 \mathrm{~m}$ between 1954-55 and $1985\left(13.3 \mathrm{~m} \cdot \mathrm{yr}^{-1}\right)$, and at $100 \mathrm{~m}$ between 1985 and 2019 $\left(2.9\right.$ m.yr $\left.{ }^{-1}\right)$. However, this setback is not linear. A minor transgressive incursion with a fluctuation of the coastline could be observed between 1985 and 1987 (Gallego Revilla and Pérez González 2018) and was estimated at $5 \mathrm{~km}$ inland in comparison to the position of 1985 (SI Fig. 4). We have also mapped a drainage shift $(1.5 \mathrm{~km})$ of the terminal course of the Tiwanaku River and delta toward the south during the 1954/1955-2019 period. The outlet and delta shifts occurred mainly during the 1954-1985 stage whereas the main stream shift occurred during the 1985-2019 stage. Furthermore, we can observe that automatic extracted drainage flows of the downstream part of the Tiwanaku River are more concordant with the 1954-1955 course than the 2019 course.

Around the Tiwanaku area (Fig. 6 and Fig. 8), we have observed some clear evidences of channel evolution since the 1930's. The stream is more meandering between 1930 and 1972 and the loops are intersected by the 2019 channel. However, some palaeochannels predate the oldest documents used 
in our study (undated paleochannels and/or canals). They are located in the northern part of the lower

408 valley. They depict an anastomosed morphology which can be linked to a wetter period whose

409 chronology cannot yet be specified. The historical geography results allow to roughly differentiate the

410 Pleistocene alluvial deposits from those related to Holocene, but it is necessary to cross combine with

411 field survey in order to better distinguish these two geomorphological features. Concerning

412 documented archaeological features, our results are in agreement with previous researches

413 (Albarracin-Jordan and Mathews 1990, Calla Maldonado 2011, Argollo 2003, Kolata 2003). The

414 agricultural terraces could not be mapped with actual aerial photography and this still requires a

415 specific field survey. On the contrary, the kochas are still visible and are mainly located on Pleistocene

416 lacustrine terraces. Ancient canals are mainly associated to Pleistocene alluvial deposits and connect

417 different part of the Holocene river courses. In the lower valley, some ancient canals correspond to the

418 extracted drainage from the ASTER GDEM. Around Tiwanaku, they seem to be connected to the

419 tributary located upstream of the archaeological site (Ojra Jahuira River). These ancient canals are

420 located between the wet grassland areas identified on the NDVI map and permanent or intermittent

421 watercourses in the lower valley and around Tiwanaku. Inside these wet areas, aerial photographs

422 showed evidences of sukka kollus attested by the presence of remnant platforms separated by small

423 canal. 


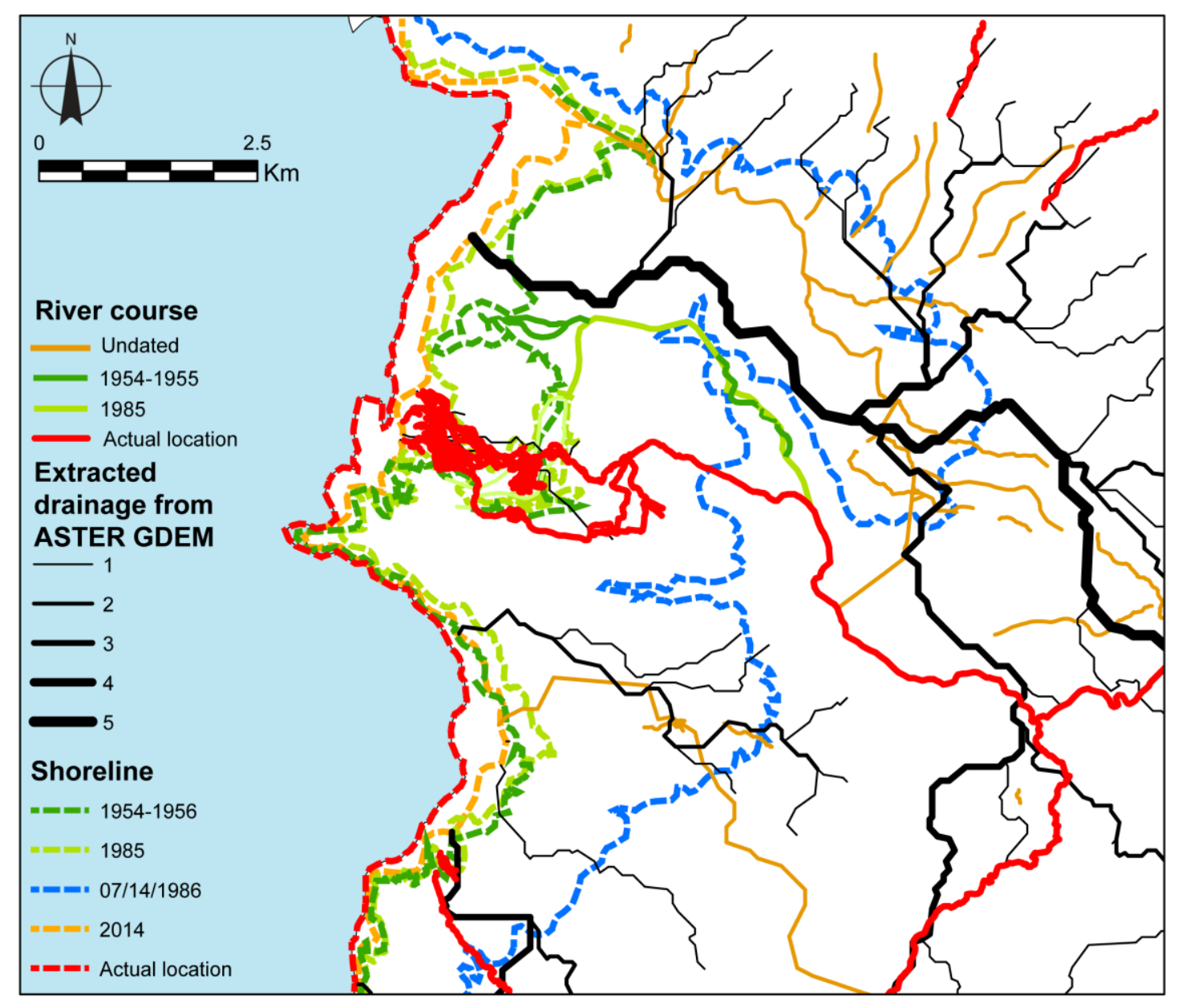

424

425 Fig. 7: Evolution of the coastline and of the Tiwanalu River since 1954-55. Location of Fig. 5 is represented in Fig 4B. 


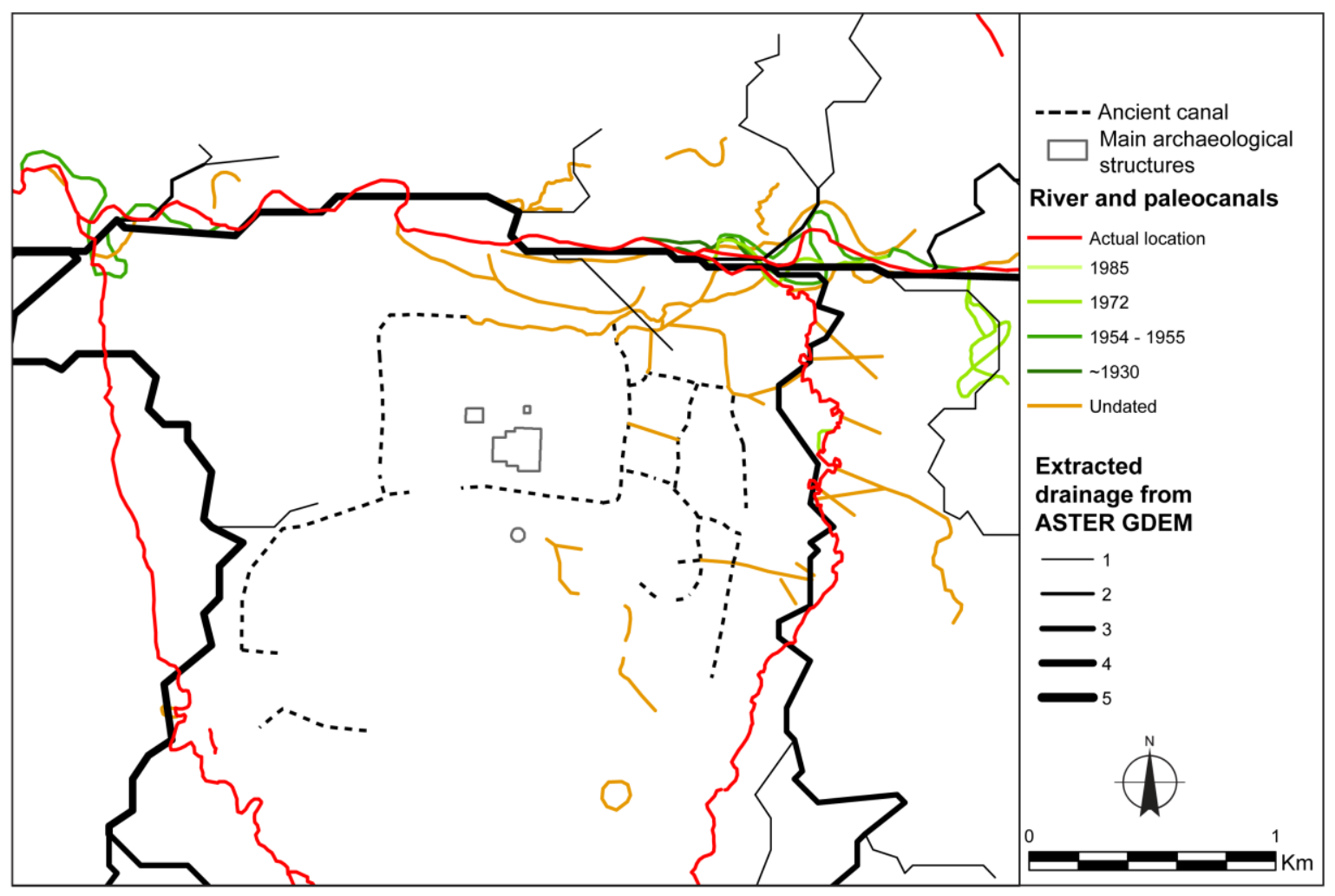

Fig. 8: Evolution of the Tiwanaku River near the Tiwanaku archaeological site since 1930'. Location of Fig. 6 is represented in Fig 4B.

\subsection{Field acquisition and observation}

432 The geomorphological features (wet grassland, slope deposits, fluvial deposit sand lacustrine deposits)

433 have been partly characterized following NDVI and slope classification and the landform evolution is specified with historical geography analysis. Field survey provided accurate details about spatial and vertical organization of landforms and superficial sedimentary deposits except high mountain area (above $4500 \mathrm{~m}$ asl) in the Quimsa Chata and Chilla massifs on the southern flank (Fig. 4A). during field surveys. They can be associated with the area of springs and bofedales or seasonal lake sectors identified by previous works, (Albarracin-Jordan and Mathews 1990, Argollo et al. 2003, Calla Maldonado 2011). However, our cartography provides more accurate details about their location, 
superficies and characteristics. Wet grasslands (bofedal, slope 0-5\%, $0.143<\mathrm{NDVI}<0.455$ ) have been

442 observed in front of the large Holocene sedimentary fans and on the Pleistocene lake terraces on the 443 southern flank (near Quimsa Chata River and above Tiwanaku archaeological site) and along the river 444 in the middle and high valley. They are compatible with the agrarian activities of the valley. Slope deposits are related to LCZ, UCZ and intermountain identified by previous studies (AlbarracinJordan and Mathews 1990, Calla Maldonado 2011). Our study, based on remote sensing cross combined with field survey, helps to refine the sedimentary composition and the spatial organization of slope deposits area. Slopes are composed of structural flats and medium to very high erosion domains. Structural flats are observed around $4500 \mathrm{~m}$ asl in the southern flank of the middle valley. They are related to bare soils and low vegetation with low erosion potential (slope 0-5\%; $0<\mathrm{NDVI}<$ 451 0.143). Medium erosion domains (slope 5-15\%) are identified at the bottom of the north and south 452 slope and are mainly composed of fine colluvium with moderately developed soils. Nowadays, the 453 most important part of the slopes is related to this geomorphological feature. Sectors of high erosion 454 (slope 15-35\%) are mostly located on the southern flank of the valley between 4100 and $4500 \mathrm{~m}$ asl 455 and present a NDVI related to bare soils, low vegetation or geological basement $(0<\mathrm{NDVI}<0.143)$. High erosion sectors are characterized by coarse colluvium, with very little developed soils, with some scree lanes mostly located on the southern slope. Sectors of very high erosion domains (>35\%) are 458 mostly related to the geological basement $(0<\mathrm{NDVI}<0.143)$.

459 Features inherited from Pleistocene and Holocene deposits are outcropping along the valley at low 460 elevation with little hilly terrain and are sometimes deeply cut by streams. We add 6 geomorphological 461 sections along the Tiwanaku valley in order to refine the distinction between Pleistocene and Holocene 462 alluvial or lacustrine deposits (Figs. 9 and 10). Currently, no archaeological elements or radiocarbon 463 chronological dates allow an accurate dating of these series. Probable Holocene lake terraces can be 464 observed at high elevation compared to seasonal lake area and are no longer under their current 465 seasonal fluctuations. On the field, these terraces present a sedimentary pattern composed of fine silty 466 clayey sediments. We have observed some alluvial plains probably dated from Holocene (slope 0-5\%; 
10). These alluvial plains are composed of non-consolidated gravel, sand and silts, is highly permeable, and has well developed soils. These areas have currently a high concentration of canals and raised fields, some of which are still of unspecified age. C3 and C5 sedimentary logs provide valuable information about stratigraphy deposits (Figs. 9 and 10). C3 stratigraphy is related to recent deposits likely date from Holocene (maximum depth $\sim 2.00 \mathrm{~m}$ ). From top to bottom, the stratigraphy is composed of silty formations (0-0.30 m depth), well-sorted red sands (0.30-0.80 m depth) and silt formation (0.80-1.20 m depth). C5 is related with early Holocene lower alluvial terrace incised by the current Tiwanaku River (maximum depth $3.50 \mathrm{~m}$ ). The stratigraphy is composed of silty formations (0-1.50 m depth) interbedded with clayey and more organic layers (1.50-3.00 m depth). We interpret this formation as a probable Holocene alluvial fan with low consolidated sediments and coarser 478 elements (gravels and pebbles) layers.

479 Pleistocene lacustrine terraces show a flat relief (slope 0-5\%), a NDVI related to bare soils and low 480 vegetation in general $(0<\mathrm{NDVI}<0.143)$ and are located between 3810 and $3940 \mathrm{~m}$ asl. The Pleistocene lacustrine terraces (Lake Michin, $3830 \mathrm{~m}$ asl, late Pleistocene and Lake Balivian, $3860 \mathrm{~m}$ asl, midPleistocene) have already been distinguished from those associated with early Holocene (Lake Tauca, $3815 \mathrm{~m}$ asl) (Argollo et al. 2003, Fritz et al. 2004, Mourguiart et al. 1998). These terrace levels are composed of an alternation of weak consolidated sand, silts and clays. The low hydraulic permeability of these formations allows them to constitute a good reservoir of surface water. C1 log show an alternation of clay formations with calcareous crust intercalations. These formations can be related to late Pleistocene lacustrine deposits (clay) with lake level variations (emerge land with calcareous 488 precipitation).

489 C2, C4 and C6 logs illustrate other sedimentary facies which contrast with the C1 one. C2 log (maximum 490 depth $\sim 2.00 \mathrm{~m}$ ) is composed of decimetric thick medium indurated sandy to silty levels and centimeter 491 thick gravel and pebble layers. C4 (maximum depth $\sim 2.50 \mathrm{~m}$ ) is characterized by silty deposits 492 interbedded with decimeter thick coarser layer composed of well sorted gravels. C6 (maximum depth 
$4941.50 \mathrm{~m}$ depth). It has been shown in previous studies in the Tiwanaku valley (Argollo et al. 2003,

495 GEOBOL 1994) and in other valley in the Lake Titicaca basin (Rigsby et al. 2003) that these sedimentary 496 deposits are compatible with Pleistocene and early Holocene alluvial fans mostly located on the 497 southern flank of the valley.

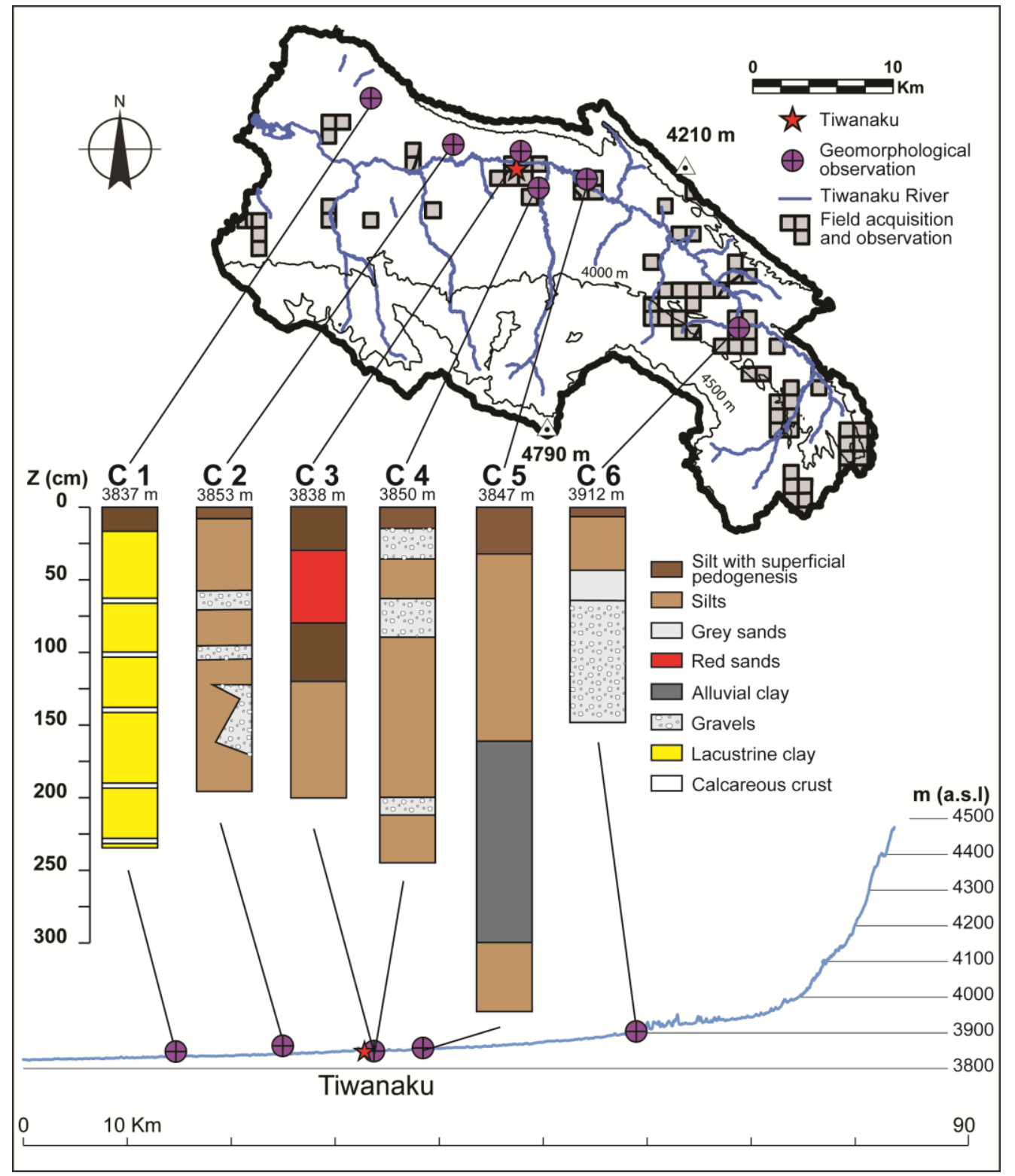

Fig. 9: Geomorphological sections along the Tiwanaku valley. Location are presented on the watershed map and along the topographic profile of the river. 


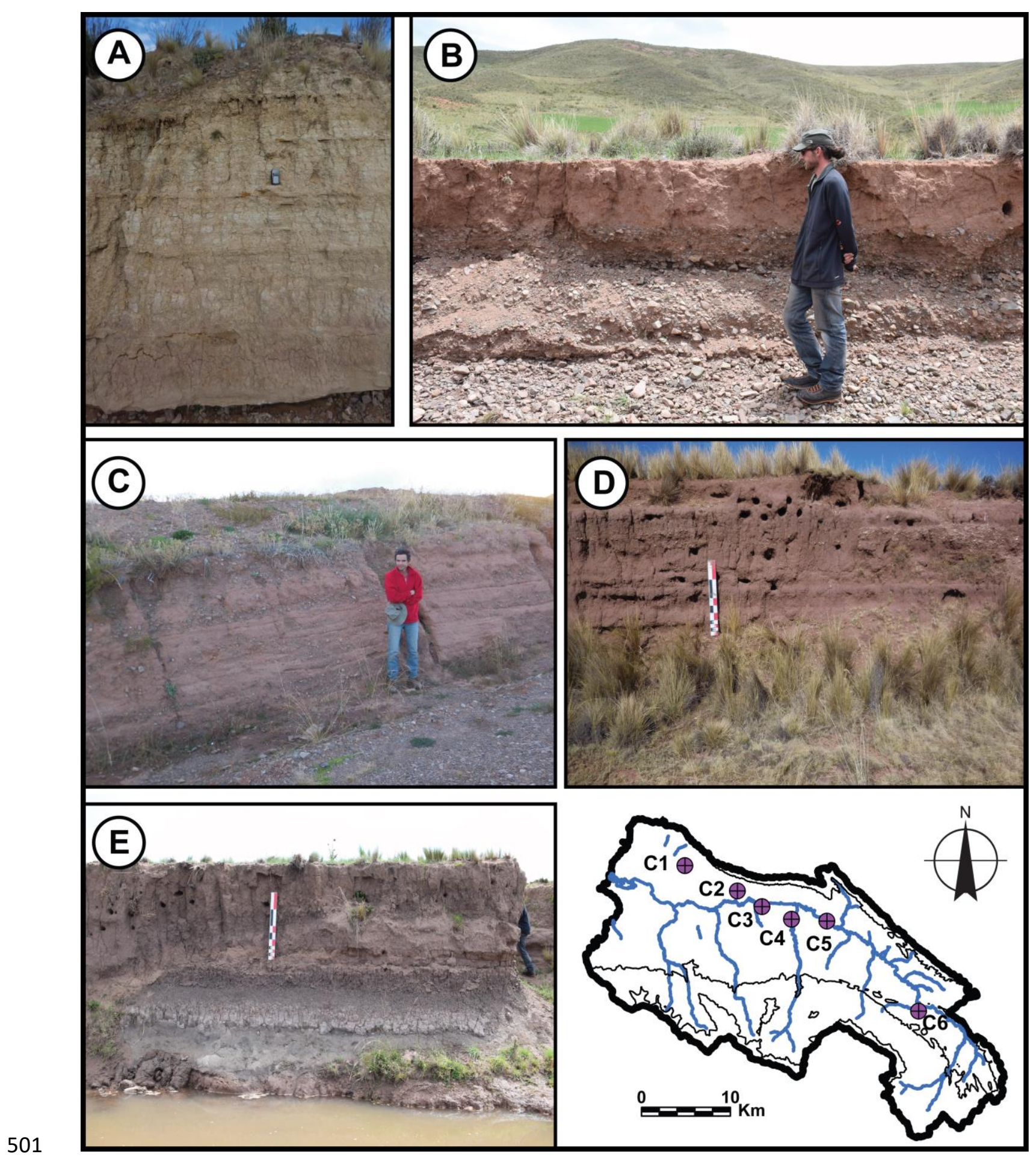

502 Fig. 10: Photo board of geomorphological observation illustrating lacustrine terraces and Quaternary

503 alluvial deposits. A: C1, late Pleistocene lacustrine deposits. B: C6, Pleistocene alluvial fans. C: C2,

504 Pleistocene alluvial fans. D: C4, Pleistocene alluvial fans. E: C5, early Holocene lower alluvial terrace. 


\subsection{Geomorphology of the Tiwanaku valley}

By leveraging remote sensing, historical photographs and field data we have restated and detailed a new cartographic synthesis of the of the Tiwanaku valley geomorphology (Fig. 11A, B and C). Our results show that the southern flank presents paleo to modern slope deposits more or less connected with Pleistocene to Holocene alluvial fans and then are connected either to Holocene alluvial formations or to Pleistocene lake levels. This pattern is also shown on the north flank, but presents almost no alluvial fans and a shorter flank. Slope classification show that high erosion areas are located in the Quimsa Chata and Chilla massifs.

The sedimentary composition of the Pleistocene lake terraces previously identified (Argollo et al. 2003) and observed on the $\mathrm{C} 1$ log indicates a high concentration of clay which may be controlled by the development of the wetlands. Alluvial fan identified on C2, C4 and C6 log is characterized by silty deposits interbedded with well sorted gravels. Recent studies on the pedogenetic processes in the Bolivian Andes, has demonstrated that in the Altiplano area, soil formation began from 3500 BP. Depositional processes related to the coarser elements identified in profiles $\mathrm{C} 2, \mathrm{C} 4$ and $\mathrm{C} 6$ must then be related to earlier periods. They might then attest to different levels of Lake Titicaca in relation with glaciation cycles during late Pleistocene period (Argollo et al. 2003) or to lake level variations during early to mid Holocene (Rigsby et al. 2003) Holocene alluvial formation observed on C3 and C5 is composed of silty formations and well-sorted red sands interbedded with clayey and more organic layers. They are probably related to respectively low and high levels of Lake Titicaca. In the lower valley, Holocene lacustrine formations are mostly located on the north bank to a distance of at least $4 \mathrm{~km}$ inland. They are associated to the Holocene delta of the Tiwanaku River whose dimensions we were able to assess at $5 \mathrm{~km}$ wide and about $6 \mathrm{~km}$ long.

Our results are therefore roughly in agreement with the major geomorphological features mapped by previous studies (Albarracin-Jordan and Mathews 1990, Argollo et al. 2003, Calla Maldonado (2011). The map produced by Albarracin-Jordan and Mathews (1990) then extended by Calla Maldonado (2011) contains information on soils and also ecosystems (fauna and flora). However, it is only based 
on altitudinal parameters and does not completely reflect the diversity of the valley's landform. In our

534 study we have, for example, shown that the LCZ is not homogeneous; this area is composed of wet

535 grassland (bofedal) separated by Pleistocene to Holocene alluvial fan. The map proposed by Argollo et

536 al. (2003) takes into account the geology and specifies the chronology of the lake terraces, but does

537 not distinguish between different categories of slope deposits and therefore the origin of sedimentary

538 sources. We have clearly shown that we can distinguish structural flat, fine colluvium, coarse colluvium

539 using slope classification and remote sensing. Our work also shows that the wet grasslands are mainly

540 located on the south bank of the middle valley. We have shown that they are associated with the

541 Pleistocene lake terraces. However, the lack of chronological control does not allow us to precise the

542 landscape evolution during Early to Late Holocene period.

543 Finally, the result of this interdisciplinary approach (i) allows to better distinguish the lacustrine and

544 alluvial forms related to the Pleistocene and Holocene, (ii) allows a better location of wet grasslands

545 (bofedal) within the valley, (iii) specifies depositional environments located on the slopes and (iv) offers

546 the first synthetized geomorphological map on the scale of a watershed combined with modern

547 landform evolution (since 60-70 years) and pre-Columbian agricultural structures in South or Central

548 America. 


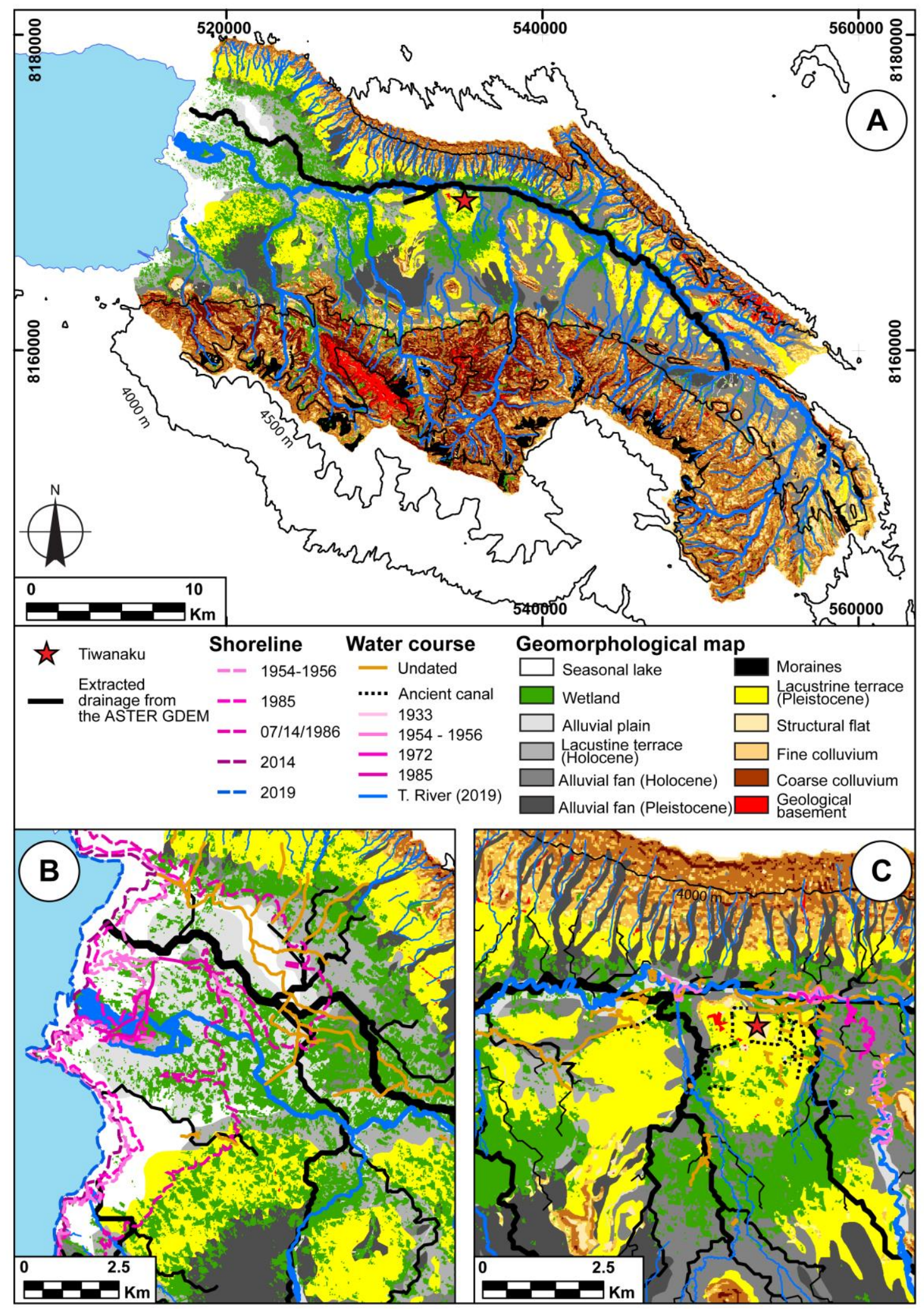

550 Fig. 11: Synthetized and extended geomorphological cartography of the Tiwanaku valley combined

551 with landform evolution since 60-70 years and probable pre-Columbian canals. A: At the scale of the

552 watershed. B: Downstream sector. C: Tiwanaku sector. 


\subsection{Landform evolution over the past $60-70$ years}

555 Historical geography results show a significant variation of rivers in the lower (Fig. 11B) and in the 556 middle valley (Fig. 11C) since the first third of the $20^{\text {th }}$ century. Furthermore, the extracted drainage 557 shows a difference with the actual course of the Tiwanaku River. From $9 \mathrm{~km}$ before its mouth into Lake Wiñaymarka, the calculated flows have a northward shift of $2 \mathrm{~km}$ on average. This difference might be related to an ancient course of the river. The association of the calculated drainage and the maximal transgressive coastline observed on the satellite image from 1986 (SI) seems to comfort this hypothesis. At the watershed scale, we note a reduction in the surface of Lake Titicaca since the second half of the $20^{\text {th }}$ century with a shift of the shore in the Tiwanaku valley of $13.3 \mathrm{~m} \cdot \mathrm{yr}^{-1}$ between $1954-55$ and 1985 and 2.9 m.yr ${ }^{-1}$ between 1985 and 2019. We have detected a delta avulsion of the River that we have estimated about $2 \mathrm{~km}$ towards the South. This shift seems to be associated with an important sediment progradation of the alluvial plain. This event could not be related to a precise date. However, considering that the last major flooding of the lake, linked to intense periods of rainfall associated with the El Niño phenomenon, was recorded in 1985-86 and 1987 (Erickson 1999, Gallego Revilla and Pérez González 2018, Roche et al 1992), we can assume that the start of this shift dates from this period.

The medium valley shows a significant displacement of alluvial forms upstream of the archaeological site of Tiwanaku (Fig. 11C). Our work highlights significant avulsion between 1954 and 1972, the decrease in the number of meander bends and the adoption of a straighter course between 1985 and 2019. Previous climatic conditions inherited from the Medieval Climatic Anomaly (MCA) and Little Ice Age 574 (LIA) period may have influenced actual landform organization. Andean glaciers can provide valuable 575 information on precipitation rates. The glaciers have experienced a major recession since the LIA 576 maximum, losing $89 \%$ of its surface area. The recession was moderate from 1940 to 1963 and 577 increased in the period 1963-1983. Since 1983, the glacier experienced a major recession rate 578 (Coudrain et al. 2005, Ramirez et al. 2001). A complete extinction of the glacier would reduce drastically 
580 al. 2001). Our observations on the retreat of the shoreline of Lake Wiñaymarka therefore seem to be 581 consistent with the decrease in precipitation on the Altiplano since the second half of the $20^{\text {th }}$ century. Historical lake-level records document numerous short- and long-term droughts and floods (Dejoux and Iltis 1992, Kessler and Monheim 1968, Monheim 1963) that can be related to modern glacial recession. There is some evidence of droughts of 36 continuous years in the $17^{\text {th }}$ century and 29 continuous years in the $18^{\text {th }}$ century (Stanish 2003). Since the beginning of the $20^{\text {th }}$ century, records show that the lake level ( 3810 $\mathrm{m}$ asl today) has fluctuated about $6.4 \mathrm{~m}$ (Roche et al 1992). Around 1914 the lake level was -1 m; between 1920-1935 the lake level was around 0 m; between 1935-1950 the lake level was located -3 m; between 1950- $1970 \sim 0$ m; between 1970-1990 +1m. During 1860 and 1959, communities confronted 15 continuous years of droughts (especially 1942 ( -3.5 m) and 1982-83 ( -0.5 m) and a record-breaking flood between 1985 and 87 (+2 m) (Erickson 1999, Kessler and Monheim 1968, Monheim 1963, Roche et al 1992, Gallego Revilla and Pérez González 2018) (SI

592 text and SI Fig. 4).

593 Major avulsion of the delta and river course shift identified since the second half of the $20^{\text {th }}$ century 594 can be related to these variations in precipitation rates and lake level. Droughts in 1982-83 followed by a record-breaking flood during 1985-86 in a larger period of lake level rise, may have influenced the shift of the shore between 1954-55 and 1985, as well as the delta avulsion. However, the mean lake level rise since the second half of the $20^{\text {th }}$ century does not control the inland migration of the shoreline in the vicinity of the Tiwanaku outlet. We propose that the shoreline migration toward the lake is due to the progression of the delta which is probably linked to an increase in the erosion processes in the upstream sectors and in sedimentation in the lower valley.

601

\subsection{Implications for ancient and current populations}


and Rigsby 2005). The river basin of the Tiwanaku River and Lake Titicaca constituted the main

606 ecosystems of the Chiripa (3500 to 1900 BP) and Tiwanaku civilization (1500-850 BP) (Janusek and

607 Kolata 2004, Kolata et al. 2000). Within the Altiplano area, combined land survey, excavation results

608 and radiocarbon dates demonstrate that the construction and use of raised field systems and

609 technology began during the late Formative Period (2200-1350 BP, Bruno 2014, Janusek and Kolata

610 2004). These agricultural structures were then developed on a large scale between 1500-850 BP during

611 favorable climatic conditions (Erickson 1999, Janusek and Kolata 2004, Kolata et al. 2000). Raised fields,

612 built in various forms, were concentrated along the lake edge, along rivers, and in the low pampas near

613 the lake and in the river floodplains (Erickson 1988, 1993, 1994, Kolata 2003, Smith et al. 1968, Stanish

614 2003). The functions of these canals include channels for reed boat traffic, water management, and

615 boundary markers for community fields and aquatic resources (Erickson 1999). The final low lake stand

616 (900-700 cal yr BP) coincides with the decline of raised field agriculture and the collapse of Tiwanaku

617 culture (Abbott et al. 1997, Janusek and Kolata 2004, Kolata et al. 2000, Ortloff and Kolata 1992). After

618 this period, local groups continued to cultivate raised fields on a much-reduced scale, as part of a more

619 diversified subsistence strategy (Stanish 2003, Janusek and Kolata 2004). Other studies assume that

620 pre-Columbian states and urban centers were ephemeral, rising and falling with some regularity in the

621 Lake Titicaca Basin (Erickson 1999, Vranich 2013). These studies demonstrated that farming

622 communities and intensive agriculture did not disappear during the post-Tiwanaku periods (Erickson

623 1999). It has been also speculated that most of the raised fields in the Katari Valley were built and

624 managed after Tiwanaku state collapse, as a local adaptation to changing sociopolitical conditions and

625 the onset of a long-term drought (Graffam 1990). This source (1990) has today been nuanced by other

626 works that demonstrated that the use of these raised field agriculture continued as relics during post-

627 Tiwanaku periods (Bruno 2014, Harstorf 2008). The appearance and development of raised field

628 technology within the circum-lacustre area of the Altiplano supports the long term tradition of

629 agricultural landscape construction observed at a larger scale from Mesoamerica (Sanders et al. 1979) 
631 times.

632 The large number of channels in the lower valley suggest that the alluvial plain morphology has 633 adopted an anastomosing organization during early Holocene (Argollo et al. 2003), probably at a period of high lake levels (Fig. 11B). However, without absolute dates, their chronology cannot be verified. The probable presence of an old course of Tiwanaku River near the northern slope of the lower valley is suggested through remote sensing and historical geography results, but its chronology cannot be defined with precision. Part of the channels that we have mapped (Fig. $11 \mathrm{~A}, \mathrm{~B}$ and C) correspond to 638 the hydraulic structures identified by previous studies which have linked them chronologically to the 639 Tiwanaku civilization (Janusek and Kolata 2004, Kolata et al. 2000, Kolata 2003, Ortloff 2014). In the 640 middle valley several linear-shaped wetlands exist near the archaeological site. These landforms can 641 be linked to a complex hydraulic network (Kolata 2003, Ortloff 2014). However, without further study 642 of the filling of these probable ancient canals, we cannot make further interpretations. As suggested 643 by recent studies (Pérez González and Gallego Revilla 2019), our work also demonstrates that these 644 canals and raised-field aimed to drain the wetlands southward of the watershed to the monumental core of Tiwanaku. These canals seem to connect different portions of the major course of the Tiwanaku River and its tributaries upstream (Kolata 2003, Ortloff 2014) and downstream (Pérez González and 647 Gallego Revilla 2019) of the archeological site of Tiwanaku. These canals also connect different wetland 648 of the valley and associate the Pleistocene lake terraces with Holocene alluvial formations of the 649 middle and the lower valley. Their implementations are therefore probably to be linked to water 650 management for both agro-pastoral and water management purposes. The situation of the 651 monumental core of Tiwanaku seems then to be surrounded by wetland to the south, the Ojra Jahuira 652 River to the East, the Challa River to the west and the Tiwanaku River to the north defining an island 653 like landscape during wet periods. The pattern of the ancient canals in peripheral parts of Tiwanaku 654 suggests that this hydraulic network could be a heritage from ancient natural palaeochannels from the 655 Ojra Jahuira River. 
Downstream of the archaeological site, on the south bank of the Tiwanaku River and on the west side

657 of the Challa River (Fig. 11C), we identified a Pleistocene or early Holocene natural channel that could

658 be identified at the same location of ancient canals (Kolata 2003). This canal allows a diversion of the main course of the Tiwanaku River, thus distinguishing a second "island" that roughly corresponds to

660

661

662

663

664

665

666

667

668

669

670

671

672

673

674

675

676

677

678

679

680

681 a Pleistocene lake terrace (Fig. 11A, B and C). In a previous work, Kolata (2003) argued for a comparable derivation process. He showed the probable presence of a canal linking the diversion and one of the main tributaries of Tiwanaku River. On the other hand, all these channels cannot be linked to a specific chronological period in the absence of absolute dates made on their sedimentary filling. More recent studies have highlighted several hydraulic structures and derivations of natural streams downstream of the archaeological site (Pérez González and Gallego Revilla 2019). Our work confirms the hypothesis that water flow could be originated in part from the southern wetland identified by our present studies. The kochas are mainly located on the Pleistocene lake terraces. They are associated to agro-pastoral structures (Janusek and Kolata 2004), however, their frequent re-use by the old and current populations makes any chrono-cultural affiliation difficult. Finally, without absolute dates in the Tiwanaku valley, the chronology of the construction of the various developments (sukka kollus, kochas, canal, river avulsion) cannot be specified.

Broader studies realized in the Andean area have demonstrated that long term drought have affected the Altiplano. The climate-collapse hypothesis (Ortloff and Kolata 1993, Abbott et al. 1997, Binford et al. 1997) versus anthropogenic environment perspective (Erickson 2000, Williams 2002) is still vigorously debated. However, the aridity signal is recorded at several location in South America during the MCA (Stine 1994) from 800 to 1200 AD. Recent studies on Lake Orurillo attest that the driest climate conditions occur between ca. 915 and 1200 AD, with a more extreme phase between 950 and 1025 AD (Arnold et al. 2021). Records from northern Peruvian coast attested a period of extreme drought during the MCA 900 to 1250 AD (Rein et al. 2004). In the north-central Andes forest regrowth was evident between 800 and 1000 AD, but this trend was reversed between 1000 and 1200 AD as drier conditions coincided with renewed land clearance, (Åkesson et al. 2020). Dry period associated 
to the MCA has been related to the decline of the Moche civilization in the north coast of Peru at 900 $A D$ (Koons and Alex 2014) and of the Wari state in central Peru at about 1000 CE (Finucane et al. 2007) suggesting that these Andean states were vulnerable to prolonged drought during the MCA (Arnold et al. 2021). Drier period associated to low lake level in Lake Wiñaymarka during this period might have significantly affected raised field agricultural system by limiting the amount of land amenable to irrigation (Arnold et al. 2021). It is also needed to underline that drastic lake level drop (between 8 and 12 m, Binford et al. 1997, Abbott et al. 1997) certainly induced important erosion in the lower valley, affecting the general landscape of the Tiwanaku civilization during the MCA.

Concerning actual populations, the raised field evidences observed during the study of ancient and recent aerial photographs reflect more relics than a real operational and integrated system (Fig. 11A, $B$ and C). However, they bear witness to the persistence of this type of agriculture in the sector to this day. It has also to be noticed that recent experimental raised fields near Lake Titicaca gave some yield during the severe 1982-1983 drought and gave excellent yields in 1985-1987, when flooding devastated other types of farms (Erickson, 1992). This demonstrate that raised field agriculture could be a rich sources of inspiration for applying ecological engineering in agriculture today (Renard et al. 2012). Our results clearly demonstrate important and rapid landscape transformations during preColumbian times. Current climate changes are associated to glacier recession, drying up of wetland and of Lake Wiñaymarka and are expected to have important consequences on agricultural activities of present populations. Increasing population in El Alto (1.5 M ha.) inside the watershed of Lake Wiñaymarka and the lack of water treatments could also lead to critical environmental situations.

\section{Conclusion}

In this paper, we have synthetized and specified the chronology of events of the Tiwanaku valley since the Recent Holocene thanks to a multi-disciplinary approach (historical geography, geomorphology, 
geophysical surveys, photogrammetry, remote sensing and cores) crossed with pre-existing

707 geomorphological data.

708 We produced a new geomorphological map showing that the Tiwanaku River watershed is composed of a mosaic of geomorphological assemblages that are organized according to the morphology of the geological substratum and the altitudinal and climatic parameters. Additionally, our work put in evidence several large wet grasslands in the middle valley sometimes in connection with the hydrographic network. Our results allow to bring new information on slope deposits and to better distinguish the lacustrine and alluvial forms related to the Pleistocene and Holocene.

Our work locates several canals probably of anthropic origin, which could be related to the Tiwanaku culture (1500-850 BP). These canals connect the wetlands, the tributaries upstream (Ojra Jahuira River) and downstream (Quimsa Chata River) of the monumental site as well as the main water course of the Tiwanaku River. This entire hydraulic system is also linked to sectors with a high concentration of ancient raised field. For the past 70 years, our work has shown a general reduction in wetlands, several river avulsion in the middle valley, a decrease in the maintenance of canals and the abandonment of ancestral cultivation techniques. In addition, the reduction in the size of the lake, associated to a major shift of the river watercourse in the delta, leads to the appearance of new lands with significant agricultural potential but is also accompanied by a decrease in favorable areas in the middle valley. However, there is still a contradiction that need to be reconciled between the consideration that ancient societies have being able to construct anthropogenic agricultural landscapes and environmental factors which act as "allogenic forcing mechanisms". As other studies, our observation support that climate and lake level variation do not explain major past social and political 727 transformations but contributed to the development of flexible and diverse subsistence practices in 728 the Titicaca Basin (Bruno et al. 2021). Further work, based on a multidisciplinary approach (geophysical 729 surveys, photogrammetry and cores), is still necessary to characterize the geometry and the 730 chronostratigraphy of the canal in the lower and middle valley in relation with recent Holocene lake 731 level change. This work will provide a better understanding of the alluvial formations that border the 
South East basin of Lake Titicaca in order to better anticipate the actual environmental challenge of

733 the populations of the Altiplano.

734

\section{5}

736

737

\section{Competing Interests}

The authors declare no competing interests.

\section{Acknowledgments}

The author would like to thank first of all the native Indigenous communities, the CIAAAT (Centro de Investigacciones Anthropologicas, Arqueologicas y Administraccion de Tiwanaku) and the MTyC (Ministerio de Turismo y Culturas) of the Plurinational State of Bolivia for facilitating the access so the field survey and the local scientific framework. We also thank the IRD (Institut de Recherche pour le Développement) and the MEAE (Ministère de L'Europe et des Affaires Etrangères) of France for the logistical and financial support. Finally, we would like to thank the Bolivian and French students who participated in the "Rio Tiwanaku Archeology and Environment project". Thanks also go to Danielle Skuy for polishing the English and the two anonymous peer reviewers who significantly helped to improve the manuscript.

\section{Financial support}

MEAE-French Ministry of Europe and Foreign Affairs, Embassy of France in Bolivia, IRD.

751

\section{Author contributions statement}

753 M.A.V. designed the study. M.A.V. performed the field acquisition, the historical geography mapping

754 and remote sensing analysis. M.A.V. and N.L. interpreted the results and wrote the manuscript. 


\section{References}

1. Abbott MB, Wolfe BB, Wolfe AP, Seltzer GO, Aravena R, Mark BG, Polissar PJ, Rodbell DT, Rowe $H D$, Vuille M 2003. Holocene paleohydrology and glacial history of the central Andes using multiproxy lake sediment studies. Palaeogeography, Palaeoclimatology, Palaeoecology, 194, pp. 123-138

2. Abbott MB, Binford MW, Brenner M, Kelts KR 1997. A $3500{ }^{14} \mathrm{C}$ yr high-resolution record of lake level changes in Lake Titicaca, Bolivia/Peru. Quaternary Research, 47, pp. 169-180.

3. Åkesson CM, Matthews-Bird F, Bitting M, Fennell CJ, Church WB, Peterson LC, Bush MB 2020. 2100 years of human adaptation to climate change in the High Andes. Nat. Ecol. Evolu. 4 (1), pp. 66-74.

4. Albarracin-Jordan J and Mathews JE 1990. Asentamientos Prehispanicos del Valle de Tiwanaku. Vol. 1. Producciones CIMA, La Paz, Bolivia.

5. Apaestegui J, Cruz FW, Sifeddine A, Vuille M, Espinoza JC, Guyot JL, Edwards L 2014. Hydroclimate variability of the northwestern Amazon Basin near the Andean foothills of Peru related to the South American Monsoon System during the last 1600 years. Clim. Past 10 (6), pp. 1967-1981.

6. Argollo J, Ticcla L, Kolata AL and Rivera O 2003. Geology, geomorphology, and soils of the Tiwanaku and Catari river basins. In Kolata A (Ed.): Tiwanaku and its hinterland: archaeology and paleoecology of an Andean civilization, 1, pp. 57-88.

7. Argollo J and Mourguiart P 2000. Late Quaternary Climate History of the Bolivian Altiplano. Quaternary International, 72, pp. 37-51.

8. Arnold TE, Hillman AL, Abbott MB, Werne JP, McGrath SJ, and Arkush EN 2021. Drought and the collapse of the Tiwanaku Civilization: New evidence from Lake Orurillo, Peru. Quaternary Science Reviews, 251, 106693. https://doi.org/10.1016/j.quascirev.2020.106693

9. Baker PA, Rigsby CA, Seltzer GO, Fritz SC, Lowenstein TK, Bacher NP and Veliz C, 2001a. Tropical climate changes at millennial and orbital timescales on the Bolivian Altiplano. Nature, 409, pp. 698701.

10. Baker PA, Seltzer GO, Fritz SC, Dunbar RB, Grove MJ, Tapia PM, Cross SL, Rowe HD and Broda JP $2001 \mathrm{~b}$. The history of South American tropical precipitation for the past 25,000 years. Science, 291, pp. 640-643.

11. Baker PA and Fritz SC 2015. Nature and causes of Quaternary climate variation of tropical South America, Quaternary Science Reviews, 124, pp. 31-47.

12. Bandy MS 2006. Early village society in the Formative Period in the southern Lake Titicaca Basin. In: Isbell WH and Silverman H (Eds.): Andean Archaeology III: North and South. Springer, New York, pp. 210-236.

13. Bandy MS 2005. Energetic efficiency and political expediency in Titicaca Basin raised field agriculture. Journal of Anthropological Archaeology, 24(3), pp. 271-296.

14. Baucom PC and Rigsby CA 1999. Climate and lake-level history of the northern Altiplano, Bolivia, as recorded in Holocene sediments of the Rio Desaguadero. Journal of Sedimentary Research, 69(3), pp. 597-611.

15. Bills BG, de Silva SL, Currey DR, Emenger RS, Lillquist KD, Donnellan A, and Worden B 1994. HydroIsostatic Deflections and Tectonic Tilting in the Central Andes: Initial Results of a GPS Survey of Lake Minchin Shorelines. Geophysical Research Letters, 21-4, pp. 293-296.

16. Binford M, Kolata AL, Brenner M, Janusek JW, Seddon M, Abbott M and Curtis J 1997. Climate Variation and the Rise and Fall of an Andean Civilization. Quaternary Research, 47, pp. 235-248.

17. Bird BW, Abbott MB, Rodbell DT, Vuille M 2011. Holocene tropical South American hydroclimate revealed from a decadally resolved lake sediment $\delta 180$ record Earth and Planetary Science Letters, 310, pp. 192-202. 
18. Bharathkumar L, Mohammed-Aslam MA 2015. Crop Pattern Mapping of Tumkur Taluk using NDVI Technique: A Remote Sensing and GIS Approach. International Conference on Water Resources, Coastal and Ocean Engineering (ICWRCOE 2015), Aquatic Procedia, 4, pp. 1397-1404.

19. Boserup E 1965. The Conditions of Agricultural Growth. Earthscan Publications, London (paperback edition, 1993).

20. Bruno MC, Capriles JM, Hastorf CA, Fritz SC, Weide DM, Domic Al Baker PA 2021. The Rise and Fall of Wiñaymarka: Rethinking Cultural and Environmental Interactions in the Southern Basin of Lake Titicaca. Human Ecology. https://doi.org/10.1007/s10745-021-00222-3

21. Bruno MC 2014. Beyond Raised Fields: Exploring Farming Practices and Processes of Agricultural Change in the Ancient Lake Titicaca Basin of the Andes. American Anthropologist, 116(1), pp. 130145. DOI: 10.1111/aman.12066

22. Calla Maldonado SA 2011. Prospección arqueológica en el valle alto de Tiwanaku, contribuciones al estudio de la evolución del asentamiento prehispánico en el valle de Tiwanaku, 279 pp.; La Paz: Universidad Mayor de San Andrés. Tesis de Grado.

23. Capriles JM, Moore KM, Domic Al and Hastorf CA 2014. Fishing and environmental change during the emergence of social complexity in the Lake Titicaca Basin. Journal of Anthropological Archaeology, 34, pp. 66-77.

24. Coudrain A, Francou B, Kundzewicz ZW 2005. Glacier shrinkage in the Andes and consequences for water resources. Hydrological Sciences Journal, 50(6), pp. 925-932. DOI:10.1623/hysj.2005.50.6.925

25. Craig N, Aldenderfer MS, Baker PA, Rigsby C 2010. Terminal Archaic settlement pattern and land cover change in the Rio llave, southwestern Lake Titicaca Basin, Peru. In: Dean RM (Ed.): The Archaeology of Anthropogenic Environments. Center for Archaeological Investigations, Southern Illinois University, Carbondale, pp. 35-53.

26. D'Allestro P and Parente C 2015. GIS application for NDVI calculation using Landsat 8 OLI images International Journal of Applied Engineering Research, 10(21), pp. 42099-42102.

27. Dejoux C and Iltis A 1992. Lake Titicaca: a synthesis of limnological knowledge. Dordrecht: Kluwer Academic Publishers.

28. Delaere C 2017. The location of Lake Titicaca's coastal area during the Tiwanaku and Inca periods: Methodology and strategies of underwater archaeology. Journal of Maritime Archaeology, 12(3), pp. 223-238.

29. Dillehay TD, Pino M, Bonzani R, Silva C, Wallner J, Le Quesne C 2007. Cultivated wetlands and emerging complexity in south-central Chile and long distance effects of climate change. Antiquity, 81, pp. 949-960.

30. Erickson CL 2003. Agricultural landscapes as world heritage: raised field agriculture in Bolivia and Peru. In: Teutonico, J.-M., Matero, F. (Eds.): Managing Change: Sustainable Approaches to the Conservation of the Built Environment. Getty Conservation Institute, Los Angeles, pp. 181-204.

31. Erickson CL 2000. The Lake Titicaca Basin: A Pre-Columbian built landscape. In Lentz D. (Ed.): Imperfect balance: Landscape transformations in the Precolumbian Americas. New York: Columbia University Press, pp. 311-356.

32. Erickson C 1999. Neo environmental determinism and agrarian collapse in Andean prehistory. Antiquity. 73(281), pp. 634-642.

33. Erickson C 1994 "Methodological Considerations in the Study of Ancient Andean Field Systems." In Miller N and Gleason K (Eds.): The Archaeology of Garden and Field. University of Pennsylvania Press, Philadelphia. pp. 111-152.

34. Erickson C 1993“The Social Organization of Prehispanic Raised Field Agriculture in the Lake Titicaca Basin." In Scarborough V and Isaac B (Eds.): Prehispanic Water Management Systems, Supplement no. 7, Research in Economic Anthropology, ed.. JAI Press, Greenwich, Conn.

35. Erickson CL 1992. Prehistoric Landscape Management in the Andean Highlands: Raised Field Agriculture and its Environmental Impact. Population and Environment: A Journal of Interdisciplinary Studies, 13(4), pp. 285-300. 
36. Erickson C 1988. An Archaeological Investigation of Raised Field Agriculture in the Lake Titicaca Basin of Peru. Ph.D. diss., Department of Anthropology, University of Illinois at Champaign-Urbana. University Microfilms, Inc., no. 8908674.

37. Farabaugh RL and Rigsby CA 2005. Climatic influence on sedimentology and geomorphology of the Rio Ramis valley, Peru. Journal of sedimentary research, 75(1), pp. 12-28.

38. Finucane BC, Valdez JE, Calderon IP, Pomacanchari CV, Valdez LM, O'Connell T 2007. The end of empire: new radiocarbon dates from the Ayacucho Valley, Peru, and their implications for the collapse of the Wari state. Radiocarbon 49 (2), pp. 579-592.

39. Fritz SC, Baker PA, Lowenstein TK, Seltzer GO, Rigsby CA, Dwyer GS, Tapia PM, Arnold KK, Ku, Ku TL and Shangde $L 2004$. Hydrologic variation during the last 170,000 years in the southern hemisphere tropics of South America Papers in the Earth and Atmospheric Sciences, 29, pp. 95-104. doi:10.1016/j.yqres.2003.08.007

40. Gallego Revilla Jl and Pérez González ME 2018. Tiwanaku, entre el cielo y la Tierra. The United Nations Educational, Scientific and Cultural Organization, UNESCO, 178 pp. https://unesdoc.unesco.org/ark:/48223/pf0000265365

41. Gandhi GM, Parthiban S, Thummalu N and Christy A 2015. NDVI: Vegetation change detection using remote sensing and GIS: A case study of Vellore District. Procedia Computer Science, 57, pp. 1199-1210.

42. GEOBOL (Geologia de Bolivia) 1994. Mapas geológicas.

43. Graffam G 1992. Beyond state collapse: rural history, raised fields, and pastoralism in the South Andes. American Anthropologist, 94(4), pp. 882-904.

44. Graffam GC 1990. Raised fields without bureaucracy: an archaeological examination of intensive wetland cultivation in the Pampa Koani Zone, Lake Titicaca, Bolivia, unpublished

45. Guérin R, Descloitres M, Coudrain A, Talbi A, Gallaire R, 2001. Geophysical surveys for identifying saline groundwater in the semi-arid region of the central Altiplano, Bolivia. Hydrological Processes, 15(17), pp. 3287-3301.

46. Hastorf CA 2005. The Upper (Middle and Late) Formative in the Titicaca Region. In: Stanish C, Cohen $A B$ and Aldenderfer MS (Eds.): Advances in Titicaca Basin Archaeology. Cotsen Institute of Archaeology, University of California, Los Angeles, pp. 65-94.

47. Hastorf CA 1999. Early Settlement at Chiripa, Bolivia, Contributions of the University of California Archaeological Research Facility, Berkeley. University of California, Berkeley.

48. IGM (Instituto Geográfico Militar) 1985. Mapas topographicas.

49. Isbell WH and Silverman $\mathrm{H}$ 2002. Andean Archaeology II. Springer.

50. Janusek JW 2008. Ancient Tiwanaku. Cambridge University Press, Cambridge.

51. Janusek JW 2004. Collapse as cultural revolution: Power and identity in the Tiwanaku to Pacajes transition. Archeological Papers of the American Anthropological Association, 14(1), pp. 175-209.

52. Janusek JW and Kolata AL 2004. Top-Down or Bottom-Up: Rural Settlement and Raised Field Agriculture in the Lake Titicaca Basin, Bolivia. Journal of Anthropological Archaeology, 23(404), pp. 430-411.

53. Kessler A and Monheim F 1968. Der Wasserhaushalt des Titicacasees nach neueren Messergebnissen (The Water Budget of Lake Titicaca, after New Measurements). Erdkunde, 22(4), pp. 275-283.

54. Kolata AL 2003. The Project Wila Jawira Research Program. In Kolata AL (Ed.): Tiwanaku and Its Hinterland: Archaeology and Paleoecology of an Andean Civilization. Vol. 2: Urban and Rural Archaeology Washington D. C.: Smithsonian Institution Press.

55. Kolata A 1996. Tiwanaku and Its Hinterland: Archaeology and Paleoecology of an Andean Civilization. Volume 1: Agroecology. Smithsonian Institution Press, Washington, DC.

56. Kolata AL, Binford MW, Brenner M, Janusek JW, Ortloff C 2000. Environmental thresholds and the empirical reality of state collapse: a response to Ericksson (1999). Antiquity, pp. 424-426 
57. Kolata AL, and Ortloff C 1996. Tiwanaku Raised-Field Agriculture in the Lake Titicaca Basin of Bolivia. In Kolata AL (Ed.): Tiwanaku and Its Hinterland: Archaeology and Paleoecology of an Andean Civilization, pp. 109-151. Smithsonian Institution Press, Washington, D.C.

58. Kolata AL and Ortloff C 1989. Thermal analysis of Tiwanaku raised field systems in the Lake Titicaca basin of Bolivia. Journal of Archaeological Science, 16, pp. 233-263.

59. Koons ML, Alex BA 2014. Revised Moche chronology based on Bayesian models of reliable radiocarbon dates. Radiocarbon 56 (3), pp. 1039-1055.

60. Lhomme JP and Vacher JJ 2002. Modelling nocturnal heat dynamics and frost mitigation in Andean raised field systems. Agricultural and Forest Meteorology, 112, pp. 179-193.

61. Martin L, Fournier M, Mourguiart P, Sifeddine A, Turcq B, Absy ML, Flexor JM 1993. Southern oscillation signal in South American palaeoclimatic data of the last 7000 years. Quat. Res., 39, pp. 338-346.

62. Monheim F 1963. Contribución a la climatología e hidrología de la Cuenca del Lago Titicaca. Puno: Universidad Técnica del Altiplano.

63. Moreau S, Roland Bosseno R, Gu XF, Baret F 2003. Assessing the biomass dynamics of Andean bofedal and totora high-protein wetland grasses from NOAA/AVHRR. Remote Sensing of Environment 85(4), pp. 516-529.

64. Moreau S and Le Toan T 2003. Biomass quantification of Andean wetland forages using ERS satellite SAR data for optimizing livestock management. Remote Sensing of Environment, 84(4), pp. 477 492.

65. Moseley ME 1983. The good old days were better: Agrarian collapse and tectonics. American Anthropologist, 85, pp. 773-799.

66. Mourguiart P, Corrège T, Wirrmann D, Argollo J, Montenegro ME, Pourchet M and Carbonel P 1998. Holocene palaeohydrology of Lake Titicaca estimated from an ostracod-based transfer function. Palaeogeography, Palaeoclimatology, Palaeoecology, 143(1-3), pp. 51-72.

67. Ortloff CR 2014. Groundwater Management in the 300 bce-1100ce Pre-Columbian City of Tiwanaku (Bolivia). Hydrol Current Res., 5(168). DOI:10.4172/2157-7587.1000168

68. Ortloff CR and Kolata AL 1992. Climate and collapse: Agro Ecological perspectives on the decline of Tiwanaku state. Journal of Archaeological Science, 20, pp. 195-221

69. Otto M, Scherer D and Richters J 201). Hydrological differentiation and spatial distribution of high altitude wetlands in a semi-arid Andean region derived from satellite data. Hydrology and Earth System Sciences, 15(5), pp. 1713-1727.

70. Pérez González ME, Gallego Revilla JI 2019. A new environmental and spatial approach to the Tiwanaku World Heritage site (Bolivia) using remote sensing (UAV and satellite images) Geoarchaeology. pp. 1-14. DOI: 10.1002/gea.21778

71. Plazas C and Falchetti AM 1990. Manejo Hidráulico Zenú. Ingenierías Prehispánicas. Fondo FEN Colombia. Instituto Colombiano de Antropología, Bogotá.

72. Rabatel A, Francou B, Jomelli V, Naveau P, Grancher D 2008. A chronology of the Little Ice Age in the tropical Andes of Bolivia $\left(16^{\circ} \mathrm{S}\right)$ and its implications for climate reconstruction. Quaternary Research, 70(2): pp. 198-212.

73. Ramirez E, Francou B, Ribstein P, Descloitres M, Guerin R, Mendoza J, Gallaire R, Pouycaud B, Jordan E 2001. Small glaciers disappearing in the tropical Andes: a case-study in Bolivia Glaciar Chacaltaya $\left(16^{\circ} \mathrm{S}\right)$. Journal of glaciology, $47(157)$, pp. 187-194.

74. Rein B, Lückge A and Sirocko F 2004. A major Holocene ENSO anomaly during the Medieval period. Geophys. Res. Lett. 31 (17). https://doi.org/10.1029/2004GL020161

75. Reichel-Dolmatoff $\mathrm{G}$ and Reichel-Dolmatoff A 1974. Un sistema de agricultura prehistorica de los Llanos Orientales. Rev. Colomb. Antropol. 13, pp. 189-200.

76. Renard D, Iriarte J, Birk JJ, Rostain S, Glaser B and McKey D 2012. Ecological engineers ahead of their time: The functioning of pre-Columbian raised-field agriculture and its potential contributions to sustainability today. Ecological Engineering, 45, pp. 30-44.

77. Revollo MM 2001. Management issues in the Lake Titicaca and Lake Poopo system: importance of developing a water budget. Lakes Reservoirs Res. Manag., 6, pp. 225-229. 
78. Rigsby CA, Baker PA, Aldenderfer MS 2003. Fluvial history of the Rio llave valley, Peru, and its relationship to climate and human history. Palaeogeography, Palaeoclimatology, Palaeoecology, 194: pp. 165-185.

79. Roche MA, Bourges JC, Mattos R 1992. Climatology and hydrology of the Lake Titicaca basin. In: Dejoux C, Iltis A. (Eds.), Lake Titicaca: A Synthesis of Limnological Knowledge. Kluwer Academic, Boston, MA, pp. 63-83.

80. Rostain S 2008. Agricultural earthworks on the French Guiana coast. In Silverman $\mathrm{H}$ and Isbell W (Eds.): Handbook of South American Archaeology. Springer/Kluwer/Plenum, New York, pp. 217233.

81. Rowe HD and Dunbar RB 2004. Hydrologic-energy balance constraints on the Holocene lake-level history of Lake Titicaca, South America. Climate Dynamics, 23(3-4), pp. 439-454.

82. Rowe HD, Guilderson TP, Dunbar RB, Southon JR, Seltzer GO, Mucciarone DA, Fritz SC, Baker PA 2003. Late Quaternary lake-level changes constrained by radiocarbon and stable isotope studies on sediment cores from Lake Titicaca, South America. Global and Planetary Change, 38(3-4), pp. 273-290. DOI: 10.1016/S0921-8181(03)00031-6

83. Rowe HD, Dunbar RB, Mucciarone DA, Seltzer GO, Baker PA and Fritz S 2002. Insolation, moisture balance and climate change on the South American Altiplano since the Last Glacial Maximum. Clim. Change, 52, pp. 175-199.

84. Sanders WT, Parsons JR and Santley R 1979. The Basin of Mexico: Ecological Processes in the Evolution of Civilization. Academic Press, New York.

85. Seltzer, G.O., Cross, S., Baker, P., Dunbar, R. and Fritz, S., 1998. High-resolution seismic reflection profiles from Lake Titicaca, Peru/Bolivia. Evidence for Holocene aridity in the tropical Andes. Geology, 26, pp. 167-170.

86. Senra EO, Schaefer CE, Corrêa GR, Gjorup DF, Reis JS and Francelino MR 2019. Holocene pedogenesis along a chronotoposequence of soils from the Altiplano to the Cordillera Real, Bolivian Andes. Catena, 178, pp. 141-153.

87. Servant M. and Fontes J.-C. 1978. Les lacs quaternaires des hauts plateaux des Andes boliviennes; premières interprétations paléoclimatiques. Cah. ORSTOM, sér. Géol., 10(1), pp. 9-23.

88. Servant M and Fontes JX 1984. Les basses terrasses fluviatiles du Quaternaire récent des Andes boliviennes. Interprétation paléoclimatique. Cab. ORSTOM, ser. Géol., 14(I), pp. 15-28.

89. Servant $M$ and Servant-Vildary S 2003. Holocene precipitation and atmospheric changes inferred from river paleowetlands in the Bolivian Andes. Palaeogeography, Palaeoclimatology, Palaeoecology, 194: pp. 187-206.

90. Servant M, Fournier M, Argollo J, Servant-Vildary S, Sylvestre F, Wirrmann D and Ybert JP 1995. La dernière transition glaciaire/interglaciaire des Andes tropicales sud (Bolivie) d'après l'étude des variations des niveaux lacustres et des fluctuations glaciaires. Comptes Rendus de l'Académie des Sciences, Paris, Séries II 320, pp. 729-736.

91. Silverman H and Isbell W 2008. Handbook of South American Archaeology. Springer Science \& Business Media.

92. Smith C, Denevan W, and Hamilton P 1968. Ancient Ridged Fields in the Region of Lake Titicaca. Geographical Journal, 134(3): pp. 353-366.

93. Spencer CS, Redmond EM and Rinaldi M 1994. Drained fields at La Tigra, Venezuelan Llanos: a regional perspective. Latin American Antiquity, 5, pp. 95-110.

94. Stanish C 2003. Ancient Titicaca. The Evolution of Complex Society in Southern Peru \& Northern Bolivia University of California Press, 338 pages.

95. Stine S 1994. Extreme and persistent drought in California and Patagonia during mediaeval time, Nature, 369, pp. 546-549.

96. Strahler AN 1957. Quantitative analysis of watershed geomorphology. Eos, Transactions American Geophysical Union, 38(6), pp. 913-920. 
97. Sylvestre F, Servant M, Servant-Vildary S, Causse C, Fournier M and Yber JP 1999. Lake-level chronology on the southern Bolivian Altiplano $\left(18-23^{\circ} \mathrm{S}\right)$ during late-Glacial time and the early Holocene. Quaternary Research, 51, pp. 54-66.

98. Talbi A, Coudrain A, Ribstein P and Pouyaud B 1999. Computation of the Rainfall on Lake Titicaca Catchment during the Holocene. Comptes Rendus de l'Académie des Sciences, Série II Fascicule A-Sciences de la Terre et des Planètes, 329(3), pp. 197-203.

99. Theissen KM, Dunbar RB, Rowe HD and Mucciarone DA 2008. Multidecadal-to century-scale arid episodes on the northern Altiplano during the middle Holocene. Palaeogeography, Palaeoclimatology, Palaeoecology, 257(4), pp. 361-376.

100. Thompson LG, Mosley-Thompson E, Brecher H, Davis M, León B, Les D, Lin PN, Mashiotta T and Mountain K 2006. Abrupt tropical climate change: past and present. Proc. Natl. Acad. Sci. 103, pp. 10536-10543.

101. Thompson LG, Mosley-Thompson E and Henderson KA 2000. Ice-core palaeoclimate records in tropical South America since the Last Glacial Maximum. J. Quat. Sci. 15, pp. 377-394.

102. Thompson LG, Davis ME, Mosley-Thompson E, Sowers TA, Henderson KA, Zagorodnov VS and Cole-Dai J 1998. A 25,000-year tropical climate history from Bolivian ice cores. Science, 282(5395), pp. 1858-1864.

103. Thompson LG, Mosely-Thompson E, Dansgaard W and Grootes PM 1986. The Little Ice Age as Recorded in the stratigraphy of the Tropical Quelccaya Ice Cap. Science, 234, pp. 361-364.

104. Touahir S, Asri A, Remini B, Saad H 2018. Prédiction de l'érosion hydrique dans le bassin versant de l'oued Zeddine et de l'envasement du barrage Ouled Mellouk (Nord-Ouest algérien). Géomorphologie: relief, processus, environnement, 24(2), pp. 167-182.

105. Tucker CJ 1979. Red and photographic infrared linear combinations for monitoring vegetation. Remote sensing of Environment, 8(2), pp. 127-150.

106. USGS (United State Geological Survey) 2015. Landsat 8 (L8) Data Users Handbook, Version 1. 0, pp. 61-62.

107. Vella MA, Sejas S, Lucero Mamani K, Rodriguez LA, Rivera Casanovas C, Guedron S, Brisset E, Bievre G, Menacho Cespedes J, Argollo J, Escobar K and Ortuño T 2018. La misión Franco-Boliviana Paleoambiente y Arqueología del Río Guaquira-Tiwanaku (Bolivia): un estudio multidisciplinario de las interacciones entre las Sociedades Antiguas y el Medioambiente. Bulletin de I'Institut Français d'Etudes Andines, 47(2), pp. 1-25.

108. Vining B and Williams PR 2020. Crossing the western Altiplano: The ecological context of Tiwanaku migrations. Journal of Archaeological Science, 113, 105046. https://doi.org/10.1016/j.jas.2019.105046

109. Vuille $M$ and Werner $M$ 2005. Stable isotopes in precipitation recording South American summer monsoon and ENSO variability: observations and model results. Climate Dynamics, 25(4), pp. 401-413.

110. Vranich A, Anderson K, Bandy M, Conklin WJ, Goldstein P, Isbell W, Janusek JW, Knobloch PJ, Moseley M, Stanish C, Seddon MT, Williams PR 2013. Visions of Tiwanaku. Cotsen Institute of Archaeology Press.

111. Walker JH 2004. Agricultural Change in the Bolivian Amazon. University of Pittsburgh, Latin American Archaeology Publications, 13. University of Pittsburgh.

112. Weide DM, Fritz SC, Hastorf CA, Bruno MC, Baker PA, Guedron S and Salenbien W 2017. A $6000 \mathrm{yr}$ diatom record of mid-to late Holocene fluctuations in the level of Lago Wiñaymarca, Lake Titicaca (Peru/Bolivia). Quaternary Research, 88(2), pp. 179-192.

113. Williams PR 2002. Rethinking disaster-induced collapse in the demise of the Andean highland states: Wari and Tiwanaku. World Archaeol. 33 (3), pp. 361-374.

114. Wirrman D 1992. Morphology and bathymetry. In: Dejoux C and Iltis A (Eds.): Lake Titicaca. A synthesis of limnological knowledge. Kluwer Academic, Dordrecht, MOBI, 68, pp. 16-22.

115. Williams PR 2002. Rethinking disaster-induced collapse in the demise of the Andean highland states: Wari and Tiwanaku. World Archaeology, 33(3), pp. 361-374. 
1062

1063

1064

1065

1066

1067

1068

1069

1070

1071

1072

1073

1074

1075

1076

1077

1078

1079

1080
116. Wilson C, Simpson IA and Currie EJ 2002. Soil management in pre-Hispanic raised field systems: micromorphological evidence from Hacienda Zuleta, Ecuador. Geoarchaeology, 17(3), pp. 261-283.

117. Wirrmann D. 1988. Paleohidrología del lago Titicaca durante el Holoceno, Memoria de la Sociedad de Ciencias Naturales La Salle, XLVlii, Supl. 2, pp. 57-67.

118. Wirrmann D. and Mourguiart P. 1995. Late Quaternary spatiotemporal limnological variations in the Altipiano of Bolivia and Peru. Quaternary Research, 43, pp. 344-354. 


\section{Supplementary information}

1082

1083

1084

1085

1086

1087

1088

1089

1090

1091

1092

1093

1094

1095

1096

1097

1098

1099

1100

1101

1102

1103

1104

1105

1106

1107

1108

1109

1110

1111

1112

\section{Remote sensing}

\subsection{NDVI}

NDVI has been the most widely used spectral vegetation indices (Moreau et al. 2003). NDVI is sensitive to relative differences in absorbed/reflected light in the red and NIR spectra. Soils and senescent vegetation converge in this region, particularly where vegetation cover is not complete (Vining and Williams 2020). Taking this into account many of studies performed on semi-arid environments involved the development of spectral indices taking into account the influence of bare, unsaturated soil backgrounds to minimize soil noise like the Soil adjusted vegetation index (SAVI) developed by Baret, Guyot, and Major (1989). However Purevdorj and Tateishi (1998) indicated the superiority of NDVI and SAVI for the estimation of the green vegetation cover, with a better performance of NDVI. Bork, West, and Price (1999) demonstrated that SAVI often resulted in either no improvement or a minimal improvement relative to NDVI.

Landsat 8 OLI/TIRS-level 2 images have been chosen with regards to the less cloud cover. 10 images were selected in order to cover all the vegetation phases during one year (SI Tab. 1). As the cloud cover was too important $(>10 \%)$ from October to March 2020 and 2019 (summer in the southern hemisphere), we choose to select best images for each month during the last decade (2014-2020). The evolution of the mean NDVI highlight the division in two distinct season (SI Fig. 1). For the purpose of our study, we selected the image of the month of September (SI Fig. 2). This map is related to the Austral winter period were most of the vegetation is senescent. It has already be noted that the continued growth and low senescence of Andean wet grasslands during the Austral dry winter is highlighted by the small variation of the green tissue cover in bofedales between summer and winter (Buttolph, 1998). The cultivated plant are then less represented and only the minimal distribution of wet grassland (totora and bofedal) are highlighted (Vining and Williams 2020).

SI Tab. 1. Characteristics and statistics of the Landsat 8 OLI/TIRS -level 2 images selected for the NDVI (source: U.S. Geological Survey)

\begin{tabular}{|l|l|l|}
\hline Date (year-month-day) & Cloud cover & NDVI \\
\hline $2016-01-22$ & $2-10 \%$ & $-0.132466<\mathrm{NDVI}<0.619581$ \\
\hline $2017-02-09$ & $2-10 \%$ & $-0.085596<\mathrm{NDV}<0.524587$ \\
\hline $2016-03-26$ & $2-10 \%$ & $-0.225118<\mathrm{NDV} \mid<0.954579$ \\
\hline $2016-04-27$ & $0-2 \%$ & $-0.253308<\mathrm{NDV} \mid<0.532051$ \\
\hline $2020-05-24$ & $0-2 \%$ & $-0.049059<\mathrm{NDV}<0.502862$ \\
\hline $2020-06-25$ & $0-2 \%$ & $-0.056490<\mathrm{NDV}<0.397137$ \\
\hline $2020-07-27$ & $0-2 \%$ & $-0.109438<\mathrm{NDV} \mid<0.370272$ \\
\hline $2020-08-28$ & $0-2 \%$ & $-0.100835<\mathrm{NDV} \mid<0.378322$ \\
\hline $2016-09-18$ & $0-2 \%$ & $-0.117255<\mathrm{NDV} \mid<0.454980$ \\
\hline $2014-10-15$ & $2-10 \%$ & $-0.215946<\mathrm{NDV}<0.560082$ \\
\hline $2015-11-19$ & $2-10 \%$ & $-0.073431<\mathrm{NDV}<0.509780$ \\
\hline $2017-12-10$ & $2-10 \%$ & $-0.022190<\mathrm{NDV}<0.429464$ \\
\hline
\end{tabular}




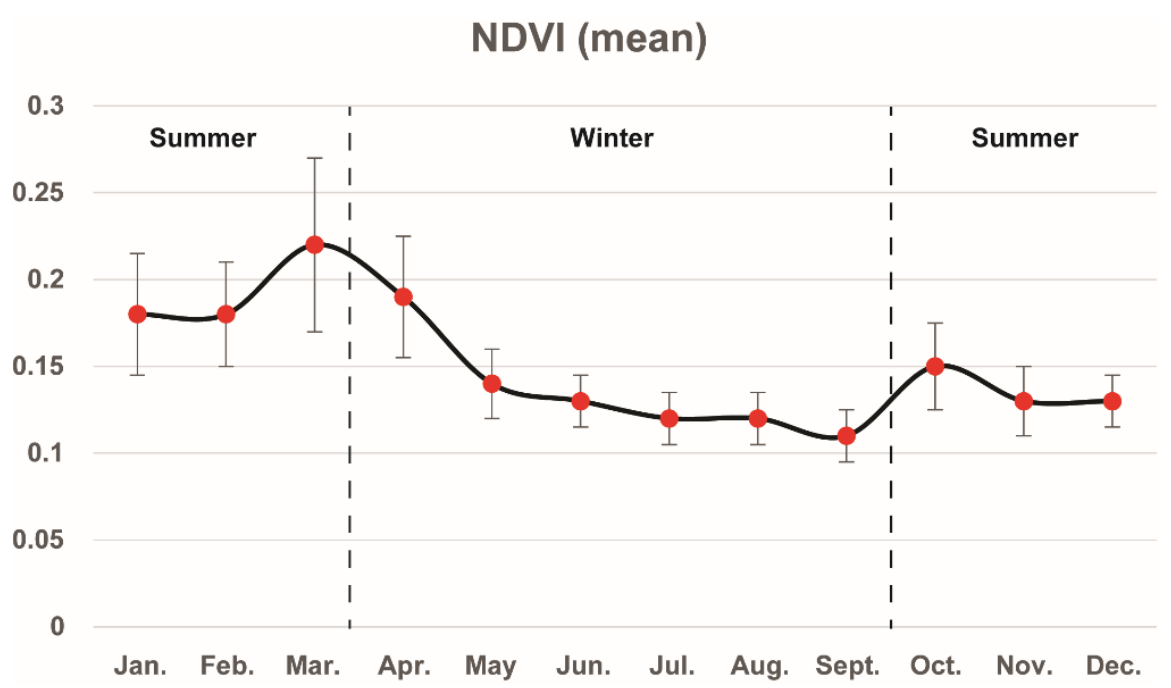

SI Fig. 1. Evolution of mean NDVI during a calendar year (Landsat 8 OLI/TIRS -level 2 images, source: U.S. Geological Survey).
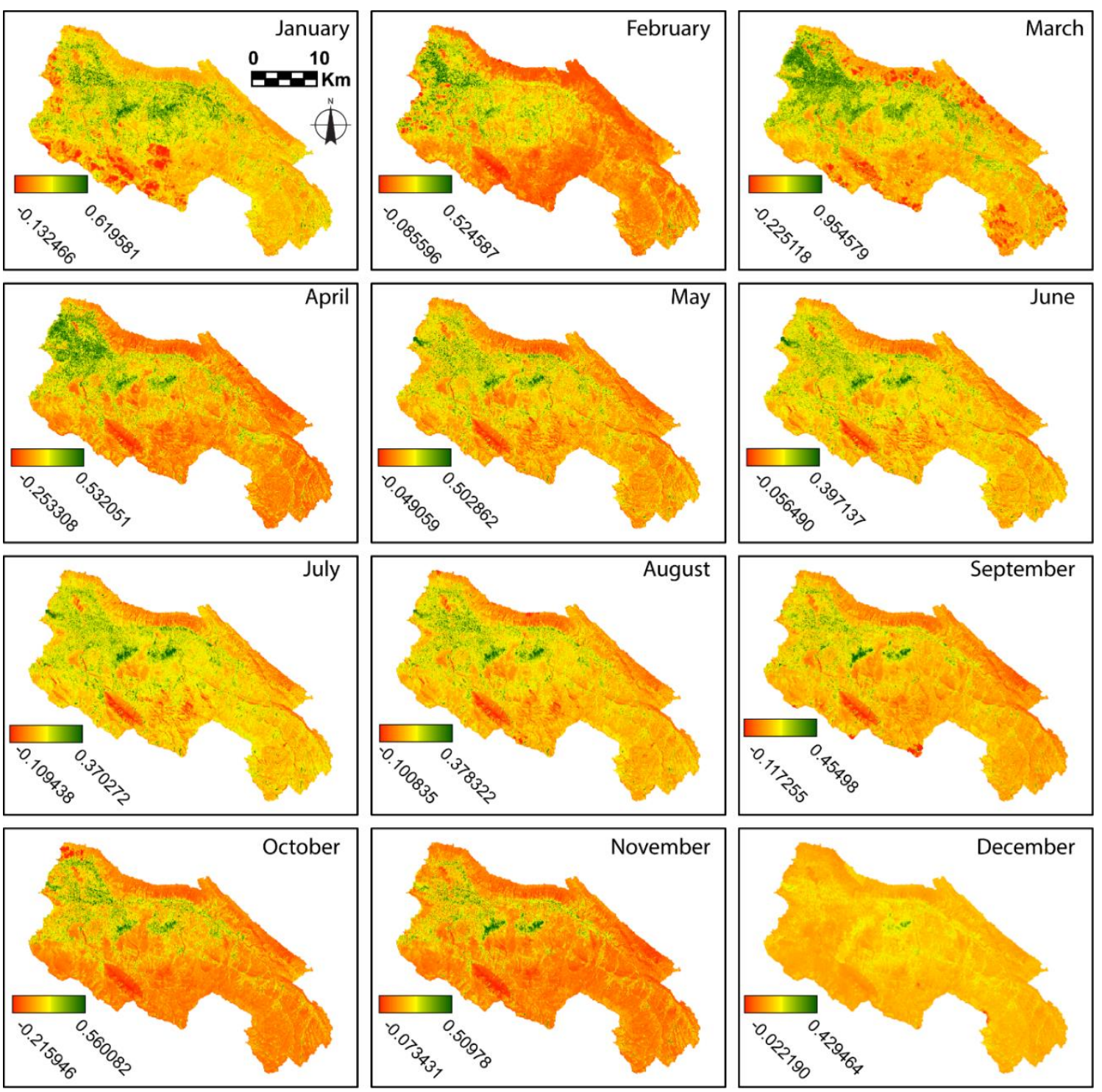

SI Fig. 2. NDVI extracted from Landsat 8 OLI/TIRS -level 2 images (source: U.S. Geological Survey). 


\subsection{Slope and drainage extraction}

National Aeronautics and Space Administration (NASA) Shuttle Radar Topography Mission Version 3.0 Global 1 arc second (SRTM 3) and Advanced Spaceborne Thermal Emission and Reflection Radiometer (ASTER) Global Digital Elevation Model Version 3 (GDEM 003) datasets were imported in an ARCGIS 10.3 environment in order to compare the influence of their respective resolution $(90 \mathrm{~m}$ and $30 \mathrm{~m})$ on the slope and drainage extraction. Cartesian coordinate system. The slope value is calculated using the average maximum technique (Arcgis Pro documentation Slope, Burrough 1998). Same procedure was used for the extraction of the slope from NASA SRTM 3 and ASTER GDEM. The slope map from both datasets show some same general tendencies. Lower values represent the main part of the valley and are located in the center of the map; medium values are located at the foot of both mountain flanks (northern and southern); higher values are observed in the southern flank of the valley. However, some differences could be identified between both dataset. First of all, the DEM from ASTER shows higher values (SRTM 3, mean slope 6.1\% and ASTER, mean slope 14.7\%). Then on the ASTER slope map, the values above $35 \%$ are more represented on the southern flank of the valley and thus highlight more the shapes of the relief in comparison with the SRTM slope map. These differences do not change the general tendencies of both datasets and might be related to the presence of noisier values on the ASTER GDEM - The flow direction can be obtained from a D8 method or MFD algorithms extracted from an initial DEM. Here we adopt the D8 method implemented in the Arcgis 10.3 software (Arcgis Pro documentation Stream Order, Tarboton 1991). The calculated flow direction is then included as an input to deduce a flow accumulation map that calculates the number of upstream cells flowing in every pixel. Thanks to a threshold value, this flow accumulation map allows to reproduce a drainage network starting from any initial DEM.

Same procedure was used for the extraction of the drainage system from the SRTM and ASTER GDEM. Flow accumulation map has been classified selecting values $\geq 1000$. Major differences from the current situation concern the drainage extracted from the SRTM 3 GDEM: the Tiwanaku River is located closer to the northern flank of the valley; the closest tributary to Lake Wiñaymarka does not join the course of the Tiwanaku River but has a mouth in the lake; the watercourse of the tributary located upstream of the archaeological site is located closer to the pre-Columbian city. However the extracted drainage from the ASTER GDEM present also some differences with current situation. Even if the Tiwanaku River is nearer to the actual watercourse, the extracted drainage is still located closer to the northern flank of the valley; the tributary associated to the archaeological site present a similar watercourse as the one observed with the SRTM 3 map. The medium vertical sensitivity and spatial resolution of the SRTM DEM clearly induced some artifacts in the extracted drainage. Although the one extracted from the ASTER GDEM seems more reliable, some differences with the current situation are still observed. These differences might still be related to the resolution of the GDEM but these discreet slope changes could also indicate some inherited topography from previous erosion phases and low lake level stands. These palaeo-flows, well developed and preserved in the topography, are indirectly found by the flow algorithm of the SIG (which fills the depressions linked to discrete divides to find an outlet). In conclusion, because of its greater resolution, ASTER GDEM and its by-products (slope and drainage) were retained for our study. 

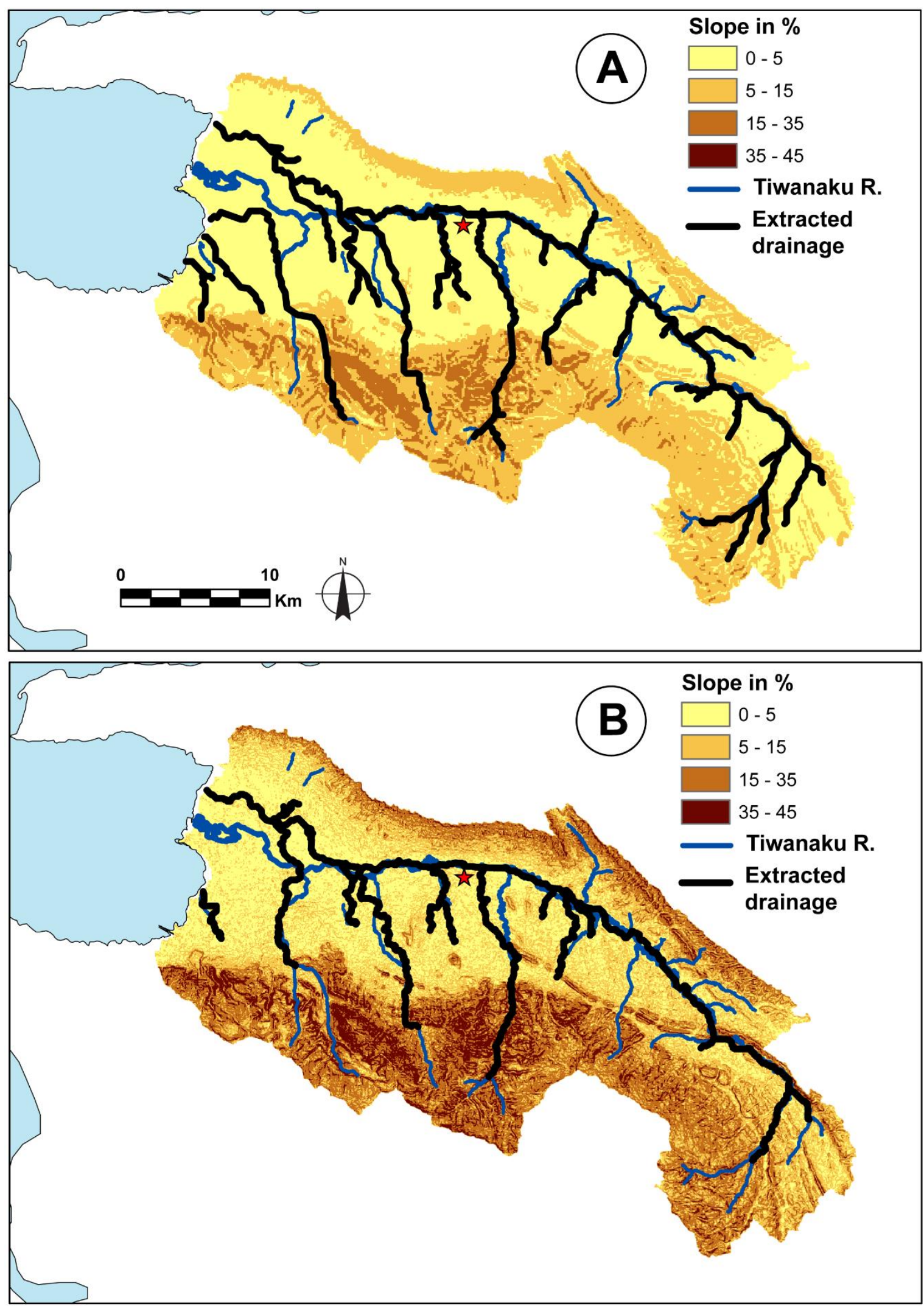

SI Fig. 3. Comparison of the DEM extracted from the SRTM and ASTER dataset (source: U.S. Geological Survey). The drainage is presented with Strahler classification (Strahler 1957). The red star represent Tiwanaku archaeological site. 


\section{Historical geography}

1173

1174

1175

1176

1177

1178

1179

1180

1181

1182

1183

1184

1185

1186

1187

1188

1189

1190

1191

1192

1193

1194

1195

1196

1197

1198

Nine set of aerial images have been gathered to reconstruct the evolution of the coastal and alluvial morphology (Main body of the article, Tab. 2).

Two satellite images (Landsat 5 TM-level 2; 1986-07-14 and 1987-08-02) allow to document the major floods observed consecutively between 1985 and 1987 (Erickson 1999, Gallego Revilla and Pérez González 2018, Roche et al 1992). The highest lake level is observed during winter 1986 (SI Fig 4). The related coastline has been extracted in order to highlight most important lake level variations and is represented in the main body of the article (Fig. 5). However for the same period, the topographical map of 1985 highlights the coastline related to years without flood (main body of the article, Fig. 5 B). The aerial images we collected allow to reconstruct the coastline evolution since 1954-1955 (Main body of the article, Fig. 5). The general pattern, without taking into consideration the extreme event of 1985-1987, is a reduction of the surface of the Lake Wiñaymarka. This decrease can be estimated at $11.4 \mathrm{~km}^{2}$ in 65 years $\left(0.17 \mathrm{~km}^{2} . \mathrm{yr}^{-1}\right)$. More details on the evolution of the coastline are given in the main body of the article.

Regarding the evolution of rivers in the lower valley (main body of the article, Fig. 5), it is possible to identify the ancient delta of the Tiwanaku River and its displacement to the current location. In the middle valley near the archaeological site of Tiwanaku (main body of the article, Fig. 6), the monumental quadrangular canal identified by previous studies (Kolata 2003, Pérez González and Gallego Revilla 2019) is clearly visible. The course of the Tiwanaku River is also clearly identifiable. Several meanders are still visible until 1972 in the area upstream of the archaeological site and are gradually adopting a straighter course.
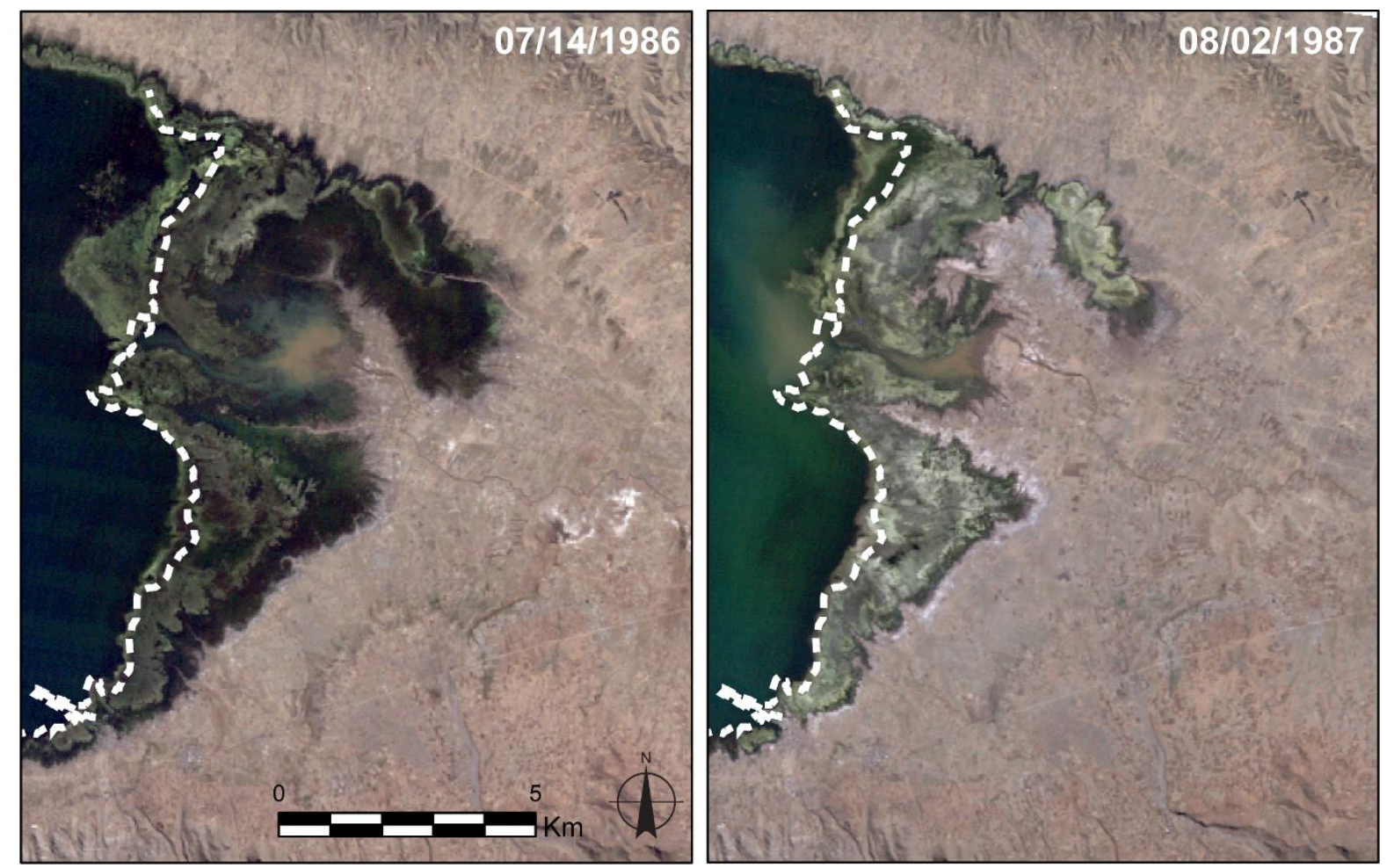

SI Fig. 4. Landsat 5-level 2 images from 1986 and 1987. The images are represented in natural colors (Band 3-2-1). The white dashed line represent the current situation of the coast line.

\section{References}


1. Arcgis Pro documentation Slope. https://desktop.arcgis.com/en/arcmap/10.3/tools/spatialanalyst-toolbox/how-slope-works.htm

2. Arcgis Pro documentation Stream Ordering. https://pro.arcgis.com/en/pro-app/latest/toolreference/spatial-analyst/how-stream-order-works.htm\#GUID-7981F8C1-C714-41A9-871EF9EDA687E1DC

3. Baret F, Guyot $G$ and Major DJ 1989. TSAVI: a vegetation index which minimizes soil brightness effects on LAI and APAR estimation. Proceedings of the 12th Canadian Symposium on Remote Sensing, Vancouver, Canada, July 10-14, pp. 1355-1358.

4. Bork EW, West NE and Price KP 1999. Calibration of broad- and narrow-band spectral variables for rangeland cover component quantification. International Journal of Remote Sensing, 20(18), pp. 3641-3662.

5. Burrough PA, and McDonell RA 1998. Principles of Geographical Information Systems (Oxford University Press, New York), 190 pp.

6. Buttolph L 1998. Rangeland dynamics and pastoral development in the High Andes: the camelids herders of Cosapa, Bolivia. PhD dissertation, Utah State University, 286 pp.

7. Erickson C 1999. Neo environmental determinism and agrarian collapse in Andean prehistory. Antiquity. 73(281), pp. 634-642.

8. Gallego Revilla JI and Pérez González ME 2018. Tiwanaku, entre el cielo y la Tierra. The United Nations Educational, Scientific and Cultural Organization, UNESCO, 178 pp. https://unesdoc.unesco.org/ark:/48223/pf0000265365

9. Kolata AL 2003. The Project Wila Jawira Research Program. In Kolata AL (Ed.): Tiwanaku and Its Hinterland: Archaeology and Paleoecology of an Andean Civilization. Vol. 2: Urban and Rural Archaeology Washington D. C.: Smithsonian Institution Press.

10. Moreau S, Roland Bosseno R, Gu XF, Baret F 2003. Assessing the biomass dynamics of Andean bofedal and totora high-protein wetland grasses from NOAA/AVHRR. Remote Sensing of Environment 85(4), pp. 516-529.

11. Pérez González ME, Gallego Revilla JI 2019. A new environmental and spatial approach to the Tiwanaku World Heritage site (Bolivia) using remote sensing (UAV and satellite images) Geoarchaeology. pp. 1-14. DOI: 10.1002/gea.21778

12. Roche MA, Bourges JC, Mattos R 1992. Climatology and hydrology of the Lake Titicaca basin. In: Dejoux C, Iltis A. (Eds.), Lake Titicaca: A Synthesis of Limnological Knowledge. Kluwer Academic, Boston, MA, pp. 63-83.

13. Strahler AN 1957. Quantitative analysis of watershed geomorphology. Eos, Transactions American Geophysical Union, 38(6), pp. 913-920.

14. Tarboton DG, Bras RL and Rodriguez-Iturbe I 1991. On the Extraction of Channel Networks from Digital Elevation Data. Hydrological Processes. 5, pp. 81-100.

15. Vining B and Williams PR 2020. Crossing the western Altiplano: The ecological context of Tiwanaku migrations. Journal of Archaeological Science, 113, 105046. 